\title{
The effect of crystallization time on plagioclase grain shape in dolerites
}

\author{
Marian B. Holness
}

Received: 25 April 2014 / Accepted: 18 October 2014 / Published online: 31 October 2014

(C) The Author(s) 2014. This article is published with open access at Springerlink.com

\begin{abstract}
The average aspect ratio of plagioclase, measured in thin section, varies systematically through dolerite sills, with a symmetrical "M"-shaped profile observed in sills thinner than $\sim 200 \mathrm{~m}$. Thicker sills show the same marginal reversal at the base, but average aspect ratios appear to continue increasing towards the top, creating an "S"shaped profile. A distorted "M"-shaped profile is visible in the stratigraphic variation of plagioclase average aspect ratios in the prehistoric Makaopuhi lava lake, with the centre of the "M" in the olivine-enriched horizon close to the base of the lake. Higher overall values of average aspect ratio are observed in thin sills compared to thicker sills, demonstrating that the plagioclase in more slowly crystallized bodies is more equant than that in more rapidly crystallized bodies. There is a strong correlation between the plagioclase average aspect ratio in the central parts of the sills and the crystallization time calculated using a simple one-dimensional thermal model assuming conductive cooling. The cause of the marginal reversals in average aspect ratio is not well understood, but may result from early grain impingement in the developing crystal mushy layer.
\end{abstract}

Keywords Plagioclase $\cdot$ Aspect ratio $\cdot$ Microstructure $\cdot$ Dolerite

Communicated by Max W. Schmidt.

M. B. Holness $(\bowtie)$

Department of Earth Sciences, University of Cambridge,

Downing Street, Cambridge CB2 3EQ, UK

e-mail: marian@esc.cam.ac.uk

\section{Introduction}

Placing constraints on the time taken for cooling and crystallization of igneous rocks is a necessary first step in determining the timescales of processes such as mass transport and compaction, or the rheological properties of partially crystallized materials. Timescales of crystallization are commonly calculated using grain size distributions (e.g. Marsh 1988), but the results of such calculations depend on accurate knowledge of grain growth rates that are not sufficiently accurately known for the low undercoolings relevant to large igneous bodies (Cashman 1993; Brugger and Hammer 2010). As will be illustrated by the present contribution, the problems associated with such an approach are amplified by the lack of sufficient information on growth rates of particular mineral faces.

Recent work has shown that the median value of the clinopyroxene-plagioclase-plagioclase dihedral angle in dolerites can be used as a direct proxy for crystallization times with no need for well-constrained growth rates (Holness et al. 2012). In this contribution, the extent to which plagioclase grain shapes can also be used to constrain crystallization times is explored.

The dependence on cooling rate of the morphology of minerals growing in silicate liquids has been extensively investigated, and the effect of increasing undercooling on the development of progressively less compact shapes such as swallowtail or hopper grains and dendrites or spherulites is well known (e.g. Lofgren 1974; Faure et al. 2003). For the low undercoolings likely to be relevant to hypabyssal and plutonic rocks, grain shapes are generally compact and facetted. This study is focused on the variation of shape of these compact grains. I present data obtained from a set of dolerite sills of varying thickness, together with a lava lake, and demonstrate a clear relationship between plagioclase 
grain shape and calculated crystallization times. The empirical correlation is then applied to the Skaergaard Campsite dykes that were the focus of a previous study of cooling rates (Holness et al. 2013).

\section{Plagioclase growth mechanisms and rates}

Growth is expected to be interface-controlled at low undercoolings, but diffusion-controlled at high undercoolings (e.g. Kirkpatrick 1975, 1981). Diffusion-controlled growth of plagioclase results in a morphological progression from swallowtails through to spherulitic forms (e.g. Lofgren 1974). The more compact forms present in hypabyssal and plutonic rocks are likely to have formed under conditions of interface-controlled growth (Lofgren 1974; Burkhard 2005).

Interface-controlled crystal growth occurs by three principal mechanisms: continuous growth, screw dislocation or surface nucleation (Kirkpatrick 1975, 1981). The continuous mechanism involves the attachment of atoms to any site on the surface and results in atomically rough surfaces. Both the screw dislocation and surface nucleation mechanisms involve lateral spreading - growth occurs by the addition of atoms to the edges of steps on the crystal surface and results in facetted crystals. If this step is a consequence of the outcropping of a screw dislocation on the growth surface, then growth can occur continuously at the step, even at low undercoolings. Surface nucleation involves the nucleation of an island of the new layer that then grows laterally: this mechanism generally requires higher undercoolings than growth via screw dislocations (Baronnet 1984). Theoretical models of crystal growth predict that materials with low entropies of fusion grow by continuous mechanisms, whereas those with large entropies of fusion (such as most silicate minerals) form crystals with atomically smooth surfaces at which growth occurs by either screw dislocation or surface nucleation (Jackson 1958; Jackson et al. 1967). Interface-controlled growth of plagioclase at the small undercoolings relevant to hypabyssal and plutonic rocks (less than a few tens of ${ }^{\circ} \mathrm{C}$ Lofgren (1974)) is primarily by surface nucleation (Kirkpatrick et al. 1976; Cabane et al. 2005), although the screw dislocation mechanism has been suggested for growth of plagioclase from hydrous granodiorite and granitic melts (Fenn 1977; Swanson 1977).

Growth rates of plagioclase are a function of cooling rate (Cashman 1993), time (Burkhard 2002; Oze and Winter 2005), decompression rate (Brugger and Hammer 2010), melt water content (Fenn 1977; Baronnet 1984) and temperature (Burkhard 2002). The presence of twins may also play a role, as twinned crystals are often observed to be larger than untwinned ones (Becke 1911) or to be distinctly flattened parallel to the (010) twin composition plane (Franke and Ghobarkar 1980). This may be an effect of the re-entrants where twin planes intersect on the crystal surface (the "re-entrant corner effect"; Stranski 1928) although this concept predates work pointing to the important role of screw dislocations in crystal growth. Kitamura et al. (1979) suggested an alternative explanation based on a high concentration of screw dislocations in the twin composition plane.

Growth rates are determined either experimentally or by analysis of natural samples for which crystallization times can be constrained. Reported values for plagioclase growth rates are based on different measures of crystal size such as the long axis (Kirkpatrick et al. 1976; Higgins 1996); short axis (Ikeda 1977; Pupier et al. 2008); the average of the long and short axes (Burkhard 2002); the diameter of the disc with the same area as each grain (Cabane et al. 2005); or the long and short axes of a best-fit ellipse through each intersected grain (Higgins and Chandrasekharam 2007; Brugger and Hammer 2010). Recent work on growth rates has relied on computer models that convert 2-D information into the presumed equivalent 3-D shape (e.g. CSD slice (Morgan and Jerram 2006) and CSD Corrections (Higgins 2000)) to obtain true, 3-D, crystal size distributions. These programs are based on the assumption of constant grain shape, regardless of grain size, and the CSD method is generally based on the assumption of constant growth rate throughout the crystallization interval. Determination of growth rates using different measures of grain size (e.g. those based on information revealed by the distribution of crystal sizes versus batch methods based on an average measure for the entire crystal population) may yield significantly different results (Brugger and Hammer 2010).

A consequence of this wide variety of approaches to the problem is that there is no straightforward way to compare different studies and no way to mine the published literature to obtain information about the relative growth rates of different crystallographic faces of plagioclase.

\section{Plagioclase morphology}

The shape of a facetted mineral grain growing in isolation is governed by the relative rates of growth of the different faces. Those faces with the highest rates of growth are the smallest, with the largest faces having the slowest growth rates. There is little detailed published information about how and why the shape of compact (as opposed to dendritic or spherulitic) plagioclase grains varies as a function of growth conditions, although Franke and Ghobarkar (1980, 1982) showed that habit for plagioclase grown hydrothermally during isothermal experiments is a strong function of temperature. For plagioclase crystallized from magma, the 

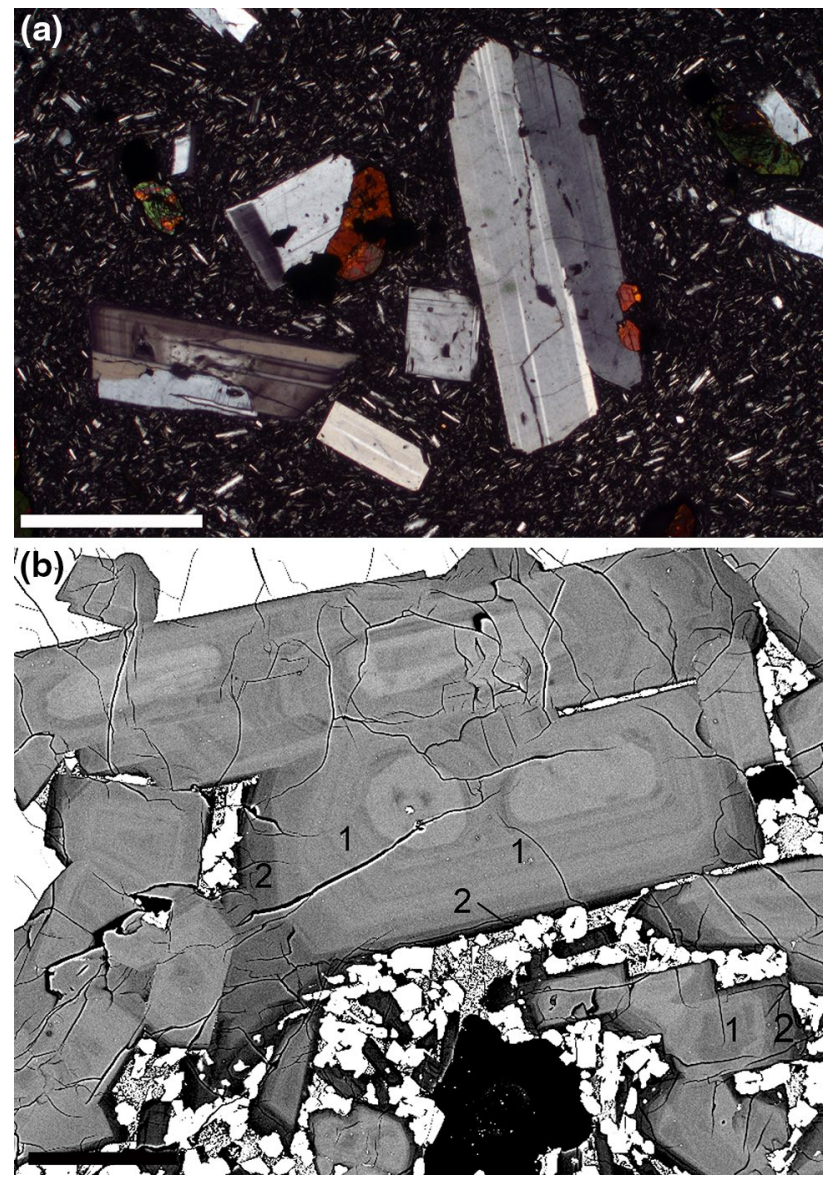

Fig. 1 a Photomicrograph (with crossed polars) of an andesite, with phenocrysts of plagioclase, hornblende and $\mathrm{Fe}-\mathrm{Ti}$ oxides in a fine-grained plagioclase-rich matrix. Note the relatively high apparent aspect ratio of the groundmass plagioclase compared to that of the phenocrysts. Scale bar is $1 \mathrm{~mm}$ long. (b) plagioclase-rich crystal clot entrained in lava flow, Iceland (sample LAK12, described in Passmore et al. (2012) and Neave et al. (2013)). Note the variable thickness of the compositional zoning of the plagioclase, with the central zones (labelled 1) of uniform thickness around the grain core, whereas the outer zones (labelled 2) are distinctly thicker on the ends of the grains compared to the $(010)$ faces. The plagioclase grew in two stages, with an earlier slow stage and a later rapid stage associated with entrainment and eruption. Scale bar is $100 \mu \mathrm{m}$ long

$x$-axis (i.e. [100]) is the direction of most rapid growth and the $y$-axis (or [010]) the direction of slowest growth (Muncill and Lasaga 1988; Higgins 1996). The available experimental data demonstrate that increasing undercoolings and cooling rates result in greater differences between the growth rates of the different faces, resulting in grains bounded by large (010) faces that are increasingly elongate parallel to [100] with increased undercoolings (Muncill and Lasaga 1988; Pupier et al. 2008). Franke and Ghobarkar (1980) also found that (isothermal) growth temperature affects habit, with more platy grains forming at high temperatures.

The general observation that the phenocrysts in most plagioclase-phyric extrusive rocks are generally more equant than plagioclase in the groundmass (Fig. 1a; Higgins 1996) is consistent with a control by cooling rate. This is also evident in the progressive change in plagioclase grain shape recorded by compositional zoning of grains that have had a poly-stage growth history (Fig. 1b). However, it has also been suggested that stirring of the magma can result in an increased departure from equant shapes (Kouchi et al. 1986).

In fully solidified rocks, the distribution of plagioclase grain shapes will be controlled not only by the relative rates of growth of the different faces, but also by the effects of impingement of the growing grains. Impingement of elongate or platy grains results in the cessation of growth in the primary growth direction, meaning that further growth must occur on the slower-growing faces (e.g. Schiavi et al. 2009), resulting in a grain population that is increasingly equant as solidification proceeds. The grain size and volume fraction of crystals at which impingement becomes important depend on the initial shape of the grains (e.g. Philipse 1996; Williams and Philipse 2003) and the nucleation density, both of which are controlled by cooling rate via the control by undercooling, though the extent of superheat in the original magma is also important (Cashman 1993). A further consideration is that individual plagioclase grains change shape during growth in liquid-rich systems (i.e. in the absence of any impingement effects), becoming blockier and more equant as they grow, perhaps as a consequence of synneusis and agglomeration (Pupier et al. 2008).

\section{Geological examples}

I chose a set of previously well-described igneous bodies (sills and a lava lake) with approximately the same magma composition (to avoid any effects of significantly different mineral mode or liquid line of descent), but widely varying size (and thus crystallization times), to explore the effects of cooling rate on plagioclase grain shape. The sills examined in this study include those that were the subject of earlier work linking dihedral angle variation with cooling timescales (the Traigh Bhàn na Sgùrra, Whin, Portal Peak and Basement Sills, Holness et al. (2012); and the Skaergaard Campsite dykes, Holness et al. (2013)). For each of the chosen bodies, the country rock was likely to have been cool since intrusion was generally shallow. Plagioclase is thought to have grown in situ in most of the bodies studied here, although the Basement Sill may have been filled with an initially plagioclase (and orthopyroxene)-phyric magma (Bedard et al. 2007). However, our Basement Sill samples contained no very large plagioclase grains so it is likely that plagioclase grain shape in our sample suite reflects controls by cooling and crystallization in situ. 


\section{The Traigh Bhàn na Sgùrra Sill}

The Traigh Bhàn na Sgùrra Sill, on the Isle of Mull (Inner Hebrides), ranges from $2.5 \mathrm{~m}$ to $\sim 8 \mathrm{~m}$ thick (Holness and Humphreys 2003). Flow through the sill was localized into the wider portions (c.f. Bruce and Huppert 1989), which are characterized by a wide thermal aureole and the absence of a well-developed chilled margin. We sampled the sill in two places, one where it is $3.5 \mathrm{~m}$ thick and where flow is inferred to have been continuous for some time (samples with prefix ROM48-this is Traverse $\mathrm{Z}$ of Holness and Humphreys (2003) at UK grid reference NM 4228918542 , or $56.289098^{\circ} \mathrm{N} 6.1661259^{\circ} \mathrm{E}$ ), and the other where the sill is $3.1 \mathrm{~m}$ thick and where the flow duration is inferred to have been short, leading to a well-developed chilled margin and a negligible thermal aureole (samples with prefix ROM43 - this is Traverse X of Holness and Humphreys (2003) at UK grid reference NM 4134818248 or $56.285952^{\circ} \mathrm{N} 6.1809986^{\circ} \mathrm{E}$ ).

The sill is a basaltic andesite and shows no significant stratigraphic variation in major element composition, with $\mathrm{SiO}_{2}$ of $54-55 \mathrm{wt} \%, \mathrm{MgO}$ of $5.6-6.2 \mathrm{wt} \%$ and total $\mathrm{Fe}$ $\left(\mathrm{FeO}+\mathrm{Fe}_{2} \mathrm{O}_{3}\right)$ of $10-11 \mathrm{wt} \%$ (Preston 1996; a single representative bulk composition (labelled SOB1) is presented by Preston et al. 1998). Groundmass plagioclase has a compositional range from core to rim of $\mathrm{An}_{66-56}$ (Preston et al. 1998). Phenocrysts are rare and the silica-rich mesostasis comprises altered glass containing dendritic crystals of oxides. Holness and Humphreys (2003) documented weak flow alignment of plagioclase in four of the Traigh Bhàn na Sgùrra samples we examined (ROM43-190, -170, -80 and -BASE).

\section{The Whin Sill}

The Whin Sill crosses northern England from Newcastle to Carlisle. The samples described here are from the Throckley borehole (UK grid reference NZ 1455767617 , or $55.002913^{\circ} \mathrm{N} 1.7739581^{\circ} \mathrm{E}$ ) where it is $38.56 \mathrm{~m}$ thick. It comprises tabular plagioclase, with interstitial Ca-rich pyroxenes and minor Fe-Ti oxides, rare orthopyroxene phenocrysts, and a silicic mesostasis of graphic intergrowths of quartz and alkali feldspar. Plagioclase core compositions vary from $\mathrm{An}_{74}$ to $\mathrm{An}_{55}$, with little systematic variation with height (Figure 4 of Dunham and Strasser-King (1981)). Bulk rock major and trace element concentrations of the samples examined here are presented by Dunham and Strasser-King (1981) and demonstrate a general compositional uniformity, with $\mathrm{SiO}_{2}$ between 49 and $50 \mathrm{wt} \%$. $\mathrm{MgO}$ exhibits a $\mathrm{C}$-shaped profile, with $6 \mathrm{wt} \%$ in the marginal $3-4 \mathrm{~m}$ and $5 \mathrm{wt} \%$ in the central portion. Total $\mathrm{Fe}\left(\mathrm{FeO}+\mathrm{Fe}_{2} \mathrm{O}_{3}\right)$ is $13.5 \mathrm{wt} \%$ at the base, decreasing to $12.6 \mathrm{wt} \%$ by $5 \mathrm{~m}$ stratigraphic height, with a subsequent increase to $13.4 \mathrm{wt} \%$ at the top of the sill.
The variation of average plagioclase grain size (from Dunham and Strasser-King (1981) and assumed to be the average long axis length) is greatest within a few metres of the margins and is approximately symmetrical across the sill. In contrast to the other bodies examined as part of this study, plagioclase grains in the Whin samples tend to cluster in groups of parallel grains with their (010) faces in contact, suggestive of synneusis and agglomeration.

\section{The Portal Peak Sill}

The Portal Peak Sill in the Queen Alexander Range, Antarctica $\left(83.83^{\circ} \mathrm{S} 165.60^{\circ} \mathrm{E}\right)$, is part of the Ferrar Dolerite Group and is a sub-alkalic low-Ti quartz dolerite. The suite of samples described here were collected from a $129-\mathrm{m}$ section through the sill. The main phases are plagioclase, augite and pigeonite, with a granophyric mesostasis. No plagioclase compositional data are available. The sill composition is essentially uniform with height (Hergt et al. 1989; Faure and Mensing 2010). The principal exception is the lower chilled margin, which has low concentrations of $\mathrm{SiO}_{2}, \mathrm{MgO}, \mathrm{Na}_{2} \mathrm{O}$ and $\mathrm{CaO}$, while $\mathrm{Al}_{2} \mathrm{O}_{3}$ and $\mathrm{H}_{2} \mathrm{O}+$ are unusually high. In the main body of the sill, the concentration of $\mathrm{SiO}_{2}$ decreases up-section from about 54 to $52 \mathrm{wt} \%$ at about $100 \mathrm{~m}$ stratigraphic height. In the upper $30 \mathrm{~m}$, the $\mathrm{SiO}_{2}$ concentration increases towards $54 \mathrm{wt} \%$. The concentration of $\mathrm{MgO}$ ranges from about 6 to $7 \mathrm{wt} \%$. The average plagioclase grain size varies asymmetrically, with the coarsest region near the top of the sill (Holness et al. 2012).

\section{The Koffiefontein Sill}

The sedimentary rocks of the Karoo Supergroup, South Africa, host a large number of dolerite sills formed during the Mesozoic breakup of Gondwanaland, penecontemporaneous with the Ferrar Group of Antarctica (a summary description of this group of sills is provided by Cawthorn 2012). A borehole drilled in 1998 by Afriore Pty. Ltd., about $20 \mathrm{~km}$ southwest of Gariep Dam in the Northern Cape Province, contains a dolerite body $290 \mathrm{~m}$ thick. This body contains two younger intrusions, recognizable by their chilled margins. The original sill, known as the Koffiefontein Sill, is 189 m thick (Slement 2010; Cawthorn 2012). The chilled margins on the two subsequent intrusions are consistent with their intrusion being sufficiently later than that of the original to have had no effect on the crystallization history of the earliest sill.

Geochemical analysis of 36 samples through the Koffiefontein Sill (Slement 2010) reveals a smooth, but subtle M-shaped profile (using the terminology of Latypov and Egorova 2013). $\mathrm{SiO}_{2}$ varies between 50 and $56 \mathrm{wt} \%$. $\mathrm{MgO}$ increases from $8 \mathrm{wt} \%$ at the base to $13 \mathrm{wt} \%$ at $24 \mathrm{~m}$ stratigraphic height, then decreases smoothly to $4 \mathrm{wt} \%$ by $160 \mathrm{~m}$ 
stratigraphic height. $\mathrm{MgO}$ then increases again to $9 \mathrm{wt} \%$ before a marginal reversal in the topmost few metres. These variations in bulk rock $\mathrm{MgO}$ are associated with variations in the concentration of olivine phenocrysts. No plagioclase compositional data are available.

\section{The Basement Sill}

The Basement Sill is the stratigraphically lowest member of the four Ferrar Dolerite Group sills exposed in the McMurdo Dry Valleys of Antarctica. In contrast to the three upper sills, which have doleritic to sub-ophitic microstructures, the microstructure of the Basement Sill is more similar to that of cumulate rocks, with a coarse-grained websterite central region under- and overlain by gabbronorite (Bedard et al. 2007). On the basis of a detailed microstructural and geochemical study, Bedard et al. (2007) suggested the sill formed from a slurry of orthopyroxene and plagioclase grains with subsequent migration and unmixing of crystals and liquid.

We examined samples from West Bull Pass $\left(77.50^{\circ} \mathrm{S}\right.$ $\left.161.83^{\circ} \mathrm{E}\right)$. The upper 9 samples of the suite were collected along a $1.86-\mathrm{km}$ East/West traverse through the sill outcrop, whereas the lower 6 were collected along a NW/SE traverse close to the basal outcrop of the sill (A. Charrier, pers. commun. 2011). Previous discussions of microstructural variation in this sample set were based on the assumption that the sill is $266 \mathrm{~m}$ thick in this locality (Holness et al. 2012). However, the sample set described by Bedard et al. (2007) was collected along essentially the same East/ West traverse as the upper 9 samples studied here (locations given in their Supplementary Appendix A1.1) and, using altitude information and the dip of the sill, Bedard et al. (2007) report a thickness of $362 \mathrm{~m}$. We accordingly adjusted the stratigraphic heights of our samples to give an overall sill thickness of $362 \mathrm{~m}$.

Groundmass plagioclase varies in composition from $\mathrm{An}_{85}$ to $\mathrm{An}_{69}$ (Figure 16 of Bedard et al. 2007). In those samples containing abundant large phenocrysts of orthopyroxene, the plagioclase is generally finer-grained than in the Portal Peak and Whin Sills. Much of the variation of average plagioclase grain size occurs at the margins, and the coarsest grain size occurs near the top of the sill (Holness et al. 2012). The marginal chill zones have a granular microstructure.

The Makaopuhi prehistoric lava lake

Makaopuhi crater occurs on the east rift zone of Kilauea volcano, Hawaii, and comprises two partially overlapping collapse pits. The larger and older east pit crater is filled with olivine tholeiite basalt to form a roughly elliptical prehistoric lava lake that was originally $\sim 1,000 \mathrm{~m}$ across the widest diameter. The subsequent collapse of the west pit sliced about $170 \mathrm{~m}$ from the widest diameter, displaying a complete transect through the lake where it is $68.6 \mathrm{~m}$ deep. The younger west crater was subsequently filled to a depth of $100 \mathrm{~m}$ by an eruption in 1965, partially obscuring the section through the prehistoric lake.

Moore and Evans (1967) provide bulk compositions, together with descriptions of the mineralogy and microstructure (including average long and short axes of plagioclase grains observed in thin section) of a suite of samples collected through the entire exposed thickness of the prehistoric lava lake before it was partially obscured by the later eruption. Further, mineral compositional data are provided by Evans and Moore (1968). We used the samples collected and described by Moore and Evans (1967) for the present study.

Bulk rock $\mathrm{SiO}_{2}$ contents are in the range 46-53 wt $\%$, with $\mathrm{MgO}$ of 6.6-19.4 wt\% (Table 1 of Moore and Evans (1967)). Stratigraphic variation of bulk rock composition is primarily the result of settling of olivine phenocrysts: the originally erupted lava contained $\sim 7 \mathrm{vol} \%$ olivine phenocrysts which sank to form an olivine-rich zone $23 \mathrm{~m}$ above the floor of the lake and an olivine-depleted zone between 30.5 and $39 \mathrm{~m}$ from the floor (Moore and Evans 1967).

The main minerals present are olivine, augite, pigeonite, feldspar, ilmenite, magnetite and apatite. The groundmass plagioclase is strongly zoned throughout, with maximum anorthite compositions ranging from $\mathrm{An}_{79}$, in the centre of the lake, to $\mathrm{An}_{68}$, near the floor (Evans and Moore 1968). Brown glass and cristobalite are common near the upper middle of the lake, and large poikilitic orthopyroxenes occur near its base.

\section{The Skaergaard Campsite dykes: a test case}

The Tertiary Skaergaard intrusion of East Greenland coast comprises approximately $280 \mathrm{~km}^{3}$ of basaltic magma intruded at the shallow crustal unconformity between Precambrian gneisses and overlying Tertiary flood basalts into a fault-bounded magma chamber (Nielsen 2004) formed at the extending continental margin. The magma crystallized as a closed system (Wager and Deer 1939). The Skaergaard intrusion is cut by two generations of steeply dipping Tertiary dykes that form part of the coastal dyke swarm of East Greenland (Brooks and Nielsen 1978; Nielsen 1978), the earlier of which comprises predominantly north-south trending basaltic and doleritic dykes (Nielsen 1978). Just north of Homestead Bay, close to the Skaergaard Peninsula (an area which has become informally known as the "campsite") are two well-exposed dykes from this generation (at $68.167^{\circ} \mathrm{N}$ $31.720^{\circ} \mathrm{W}$ ). One is a $6-\mathrm{m}$ wide composite dyke known as the Campsite Dyke (Jakobsen et al. 2010, following Irvine et al. 1998), and the other (the plagioclase-phyric Dyke) is $6.5 \mathrm{~m}$ wide and contains numerous $\mathrm{cm}$-scale phenocrysts of 
plagioclase. Core compositions of plagioclase in the plagioclase-phyric Dyke and in the central part of the Campsite Dyke are in the range $A_{744}$, Jakobsen et al. (2010). The two dykes have similar bulk compositions, with $\mathrm{SiO}_{2}$ of $46-$ $48 \mathrm{wt} \%$ and $\mathrm{MgO}$ of 6.3-7.6 wt\% (full bulk compositional data are provided by Jakobsen et al. 2010).

These dykes are of particular importance as the Campsite Dyke contains abundant cumulate xenoliths that have been linked to the underlying parts of the Skaergaard intrusion (Jakobsen et al. 2010; Holness et al. 2013). Thus, the timing of dyke emplacement is of paramount importance for establishing these xenoliths as indicators of the contemporaneous chemical and microstructural state of the underlying plumbing system.

The relative age of the two dykes cannot be determined from field relations as no cross-cutting relationships are exposed (Irvine et al. 1998). Furthermore, both dykes have chilled margins and there is no field evidence that can be used to date dyke injection relative to the cooling history of the host. However, Holness et al. (2013) argued, using dihedral angle data, that the Campsite Dyke formed when the Skaergaard intrusion was still hot $\left(920-970{ }^{\circ} \mathrm{C}\right)$, whereas the host intrusion had cooled substantially more, below $670{ }^{\circ} \mathrm{C}$, at the time the plagioclase-phyric Dyke intruded. Accordingly, one might expect the plagioclase grain shape in the more slowly cooled Campsite Dyke to be different to that in the more rapidly cooled plagioclase-phyric Dyke. Four samples were examined, two collected from the central part of each dyke, to test this hypothesis.

\section{Analytical methods}

Measures of grain size in thin section are subject to the difficulties inherent in estimating true crystal sizes from 2-D sections. These difficulties arise because randomly oriented 2-D sections through a grain population create intersections with an apparent size rather than true size. There is a statistically greater likelihood of intersecting the larger grains, and identifying the true 3-D shape of the grains is not straightforward. Numerical modelling of randomly cut sections through a unimodal population of rectilinear parallelepipeds (i.e. a population of equal-sized grains of the same shape) demonstrates that the mode of the populations of width/ length ratios is the same as the ratio of the short $(S)$ to the intermediate ( $I$ ) axis lengths ( $S / I$, Higgins 1994). While natural grain populations are unlikely to have either uniform size or shape, and plagioclase grains are not entirely orthogonal, their shape is probably close enough to use the mode of the width/length distribution to estimate a general value of $S / I$ for the population as a whole. It is much less straightforward to constrain the ratio $I / L$. It can be estimated from the skew [defined as (mean - mode)/standard deviation] of the distribution of short/long ratios in thin section (Higgins 1994). Morgan and Jerram (2006) developed a method of constraining both $S / I$ and $I / L$ by fitting the observed distribution to model distributions. Higgins and Chandrasekharam (2007) relied on direct observation of plagioclase grains on broken surfaces to ascertain $I / L$.

The long and short axes of up to 500 plagioclase grains were drawn by eye on digital photographs of thin sections under crossed polars (Fig. 2). The magnification was chosen such that all grains could be distinguished in the image, and care was taken to distinguish between individual grains in clusters (e.g. in the Whin sill samples). Up to five individual photographs were used for each sample, and all discernible grains were measured in each photograph. Those grains truncated by the edge of the photograph were omitted. The ratio of long and short axis was calculated for each grain using the software package ImageJ to calculate the best-fit ellipse for each grain. The algorithm used by ImageJ to calculate the best-fit ellipse for a pair of orthogonal lines results in an aspect ratio higher than the true one by an exponent of 1.5. The need to account for this uniform scaling is offset by the simplicity and speed of the method, and the large number of samples that were required for the present study.

The numbers of individual grains measured in each sample are insufficient to place tight constraints on the mode of the aspect ratio of the population of 2-D grain shapes. The median and average aspect ratios of the grain shape population in each sample are closely related [median $=(0.979 \times$ average $\left.)-0.13, R^{2}=0.972\right]$ to the lower values of the medians attributable to the skewed population. For clarity, the discussion in this contribution will focus on the average values of apparent (2-D) aspect ratios.

The $2 \sigma$ confidence interval on the average aspect ratio was constrained using bootstrap sampling: a method suitable for populations of measurements for which the shape of the underlying distribution is unknown. One hundred populations each of 100 measurements were created by random sampling of the original population of measurements to obtain the upper and lower confidence intervals about the mean of the original sampled population.

The average grain size was determined from the same photographs, by drawing lines marking the long axis of each plagioclase grain and using the perimeter function of ImageJ. Grain sizes determined using this method for the Basement, Portal Peak and the ROM48 traverse across the Traigh Bhàn na Sgùrra Sill have previously been reported by Holness et al. (2012). The populations of short axes were determined for four representative samples (see later discussion).

Constraining the population of true 3-D grain shapes would require time-consuming procedures, such as serial sectioning or 3-D scanning, and so the present study relies on the average apparent (2-D) aspect ratio, which may 
Fig. 2 a Photomicrograph (with crossed polars) of sample 87-110 from the Portal Peak Sill. b Lines showing the long and short axes of each grain. Scale bar is $1 \mathrm{~mm}$ long

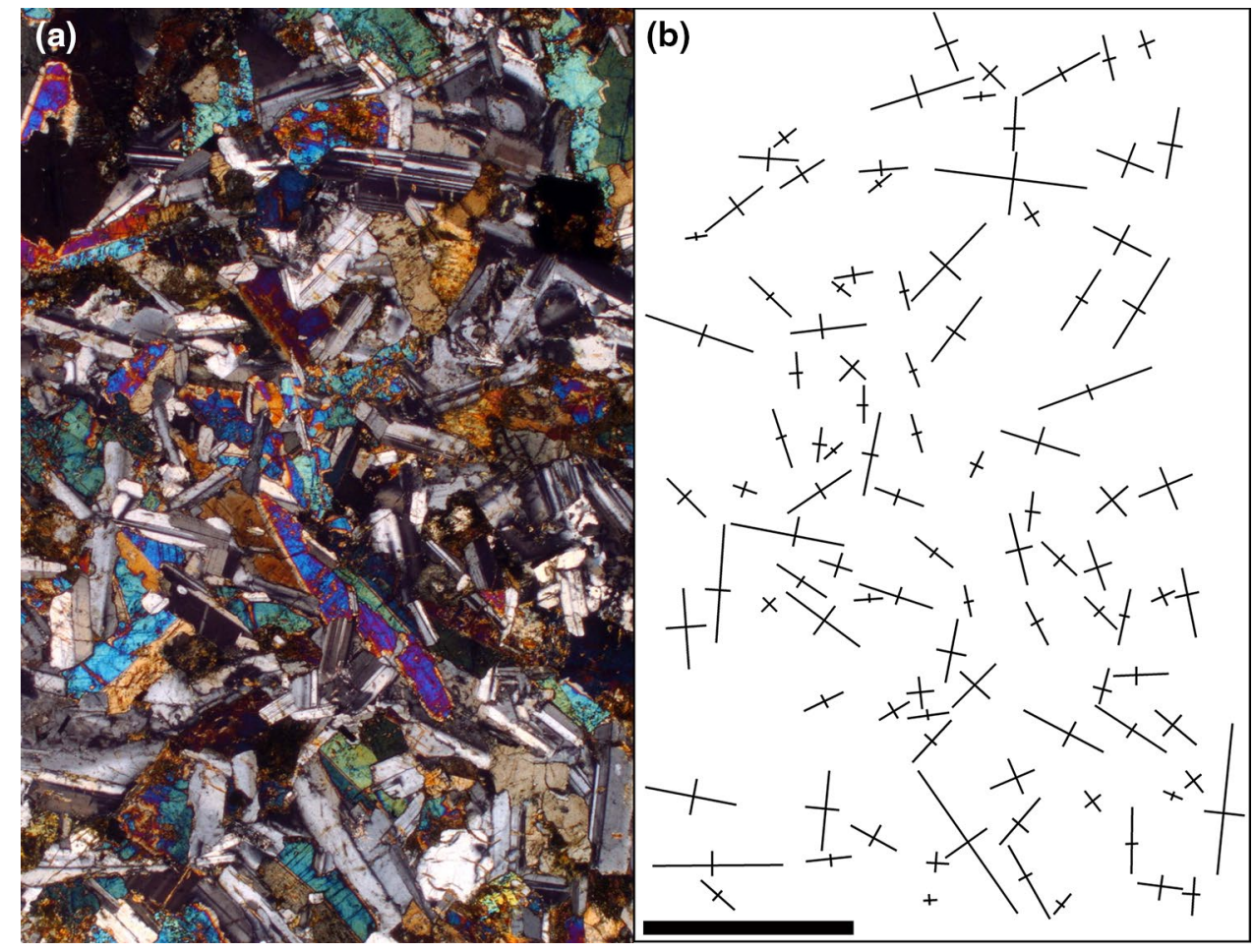

not reflect the true 3-D average aspect ratio of the grains in each sample. However, because plagioclase is generally randomly oriented in our samples (with the exception of four samples with a weak fabric from Traigh Bhàn na Sgùrra, Holness and Humphreys 2003), as long as enough grains are measured to give a representative population, the average apparent aspect ratio is a reproducible (and rapidly acquired) parameter that is representative of the sample although its relationship to the true 3-D grain shape or range of grain shapes being unknown.

\section{Crystallization times}

Thermal modelling of each intrusion was based on the 1-D heat transfer model of Holness et al. (2012), assuming purely conductive heat transfer, using the following equation:

$\left(1+L_{\mathrm{T}}\right) \frac{\partial T}{\partial t}=\kappa \frac{\partial^{2} T}{\partial \mathrm{x}^{2}}$,

where $L_{\mathrm{T}}$ is a latent heat function, $T$ is temperature and $\kappa$ is the thermal diffusivity. The initial condition is a boxcar function, of width $w$ and amplitude $T_{0}$, representing the width and initial temperature of the intrusion. The far-field temperature is set at zero, with $\kappa=10^{-6} \mathrm{~m}^{2} \mathrm{~s}^{-1}$, and $L_{\mathrm{T}}$ is calculated from MELTS using a typical basaltic composition (Ghiorso 1997).

We calculated the time in years, $\tau$, taken to cool from an assumed intrusion temperature of $1,200-1,000{ }^{\circ} \mathrm{C}$ as a function of distance from the centre of each sill. Following Cashman (1993), we assumed that this gives the time taken to crystallize basaltic magma. For diffusive cooling, the overall crystallization time scales with the square of the sill width, and the functional form of $\tau$ across each sill can be calculated numerically. A good approximation is given by:

$\tau=0.1 \frac{w^{2}}{\kappa}\left(1+\cos \left(\frac{2 \pi x}{w}\right)\right)$,

where $x$ is the position within the sill, measured from the centre, such that $x / w= \pm 0.5$ on the contacts.

This equation could not be used to model the asymmetric cooling history of the lava lake. Instead, crystallization times for samples from the prehistoric Makaopuhi lava lake were obtained from Figure 7 of Moore and Evans (1967) in which they show calculated cooling times for specific depths in the lake. Difficulties in extrapolating from their chosen depths meant that cooling times could not be determined for the top and base of the lake.

\section{Results}

Grain shape in individual samples

The characteristics of the populations of long and short axes were explored using four samples that span the range of plagioclase morphologies. ROM48-24 (a sample from 
Fig. 3 Frequency plots (normalized to 100 to permit comparison) for the long and short axes of plagioclase grains measured in thin sections of four representative samples. The average apparent aspect ratios increase in the order AC-13, MP151, MP70 and ROM48-24

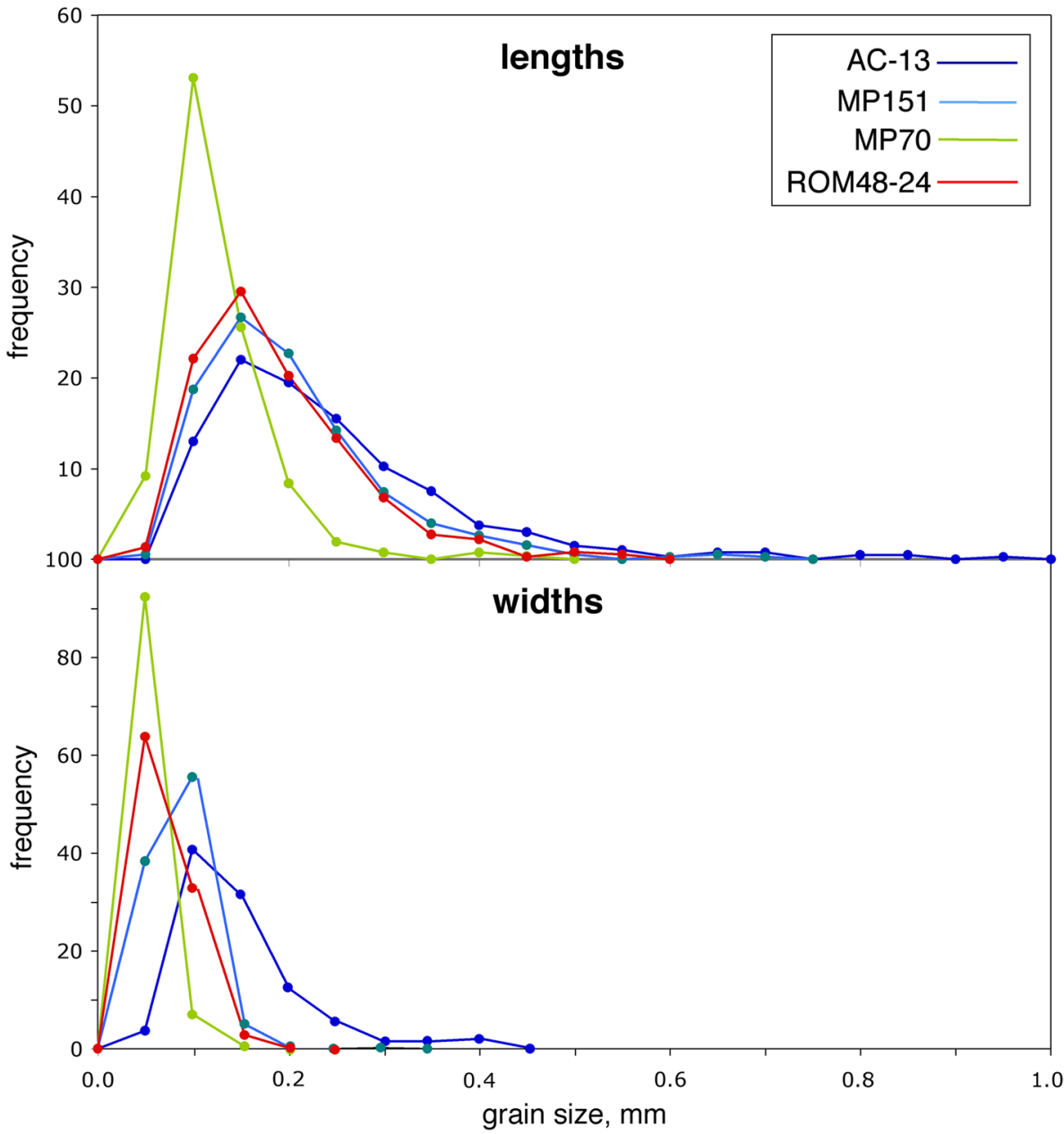

the margins of the thinnest sill examined) contains the most elongate plagioclase in thin section, whereas AC-13 (the sample from the centre of the thickest sill examined) contains the most equant plagioclase. Two additional samples were chosen from the Makaopuhi lava lake with microstructures (and crystallization times) intermediate to these two extremes: MP151 contains the most equant plagioclase in the lake, whereas MP70 has the least equant plagioclase. The frequency distributions of the short and long axes are shown in Fig. 3. The spread in each sample increases as the plagioclase becomes more equant (Fig. 3).

If it is assumed that each sample contains plagioclase of uniform grain shape, the results of Higgins (1994) can be used to place constraints on this shape. The frequency of intersected long axes for each of the four samples is unimodal, with a well-defined peak (Fig. 3). The frequency of the width/length ratio (i.e. the inverse of the aspect ratio used here, to permit direct comparison with the results of Higgins (1994)) has a single sharp peak for ROM4824 and MP70, although the spread of width/length ratios for MP151 and AC-13 is rather broad (Fig. 4). Assuming that the mode of the population of apparent aspect ratios provides the ratio of the short $(\mathrm{S})$ axis and the I axis and using Higgins (1994) method of constraining the ratio of the intermediate to long axis, plagioclase forms tablets with true 3-D aspect ratio in AC-13 of 1:2:4, in MP151 of $1: 3: 7$, in MP70 of $1: 4: 12$, and in ROM48-24 of $1: 5: 13$. Although this approach may not be valid for natural samples, which are likely to contain a range of grain shapes, it might suggest that the plagioclase shape in the slowest cooled sample (AC-13) is a thick tablet, whereas samples that crystallized over shorter timescales contain thinner and more bladed plagioclase grains. This trend differs from that suggested by Higgins (1996) that rapidly grown grains are tablets, whereas slower-growing grains tend towards elongate square prisms.

Variation of averaged grain shapes

The average aspect ratio shows significant spatial variation through all the bodies investigated here, although there is a broad pattern of generally higher average aspect ratio in the thinner sills compared to the thicker (Table 1). In sills $<200 \mathrm{~m}$ thick, the average aspect ratio varies in 
Fig. 4 Frequency (normalized to 100 to permit comparison) of apparent width/length ratios in four representative samples

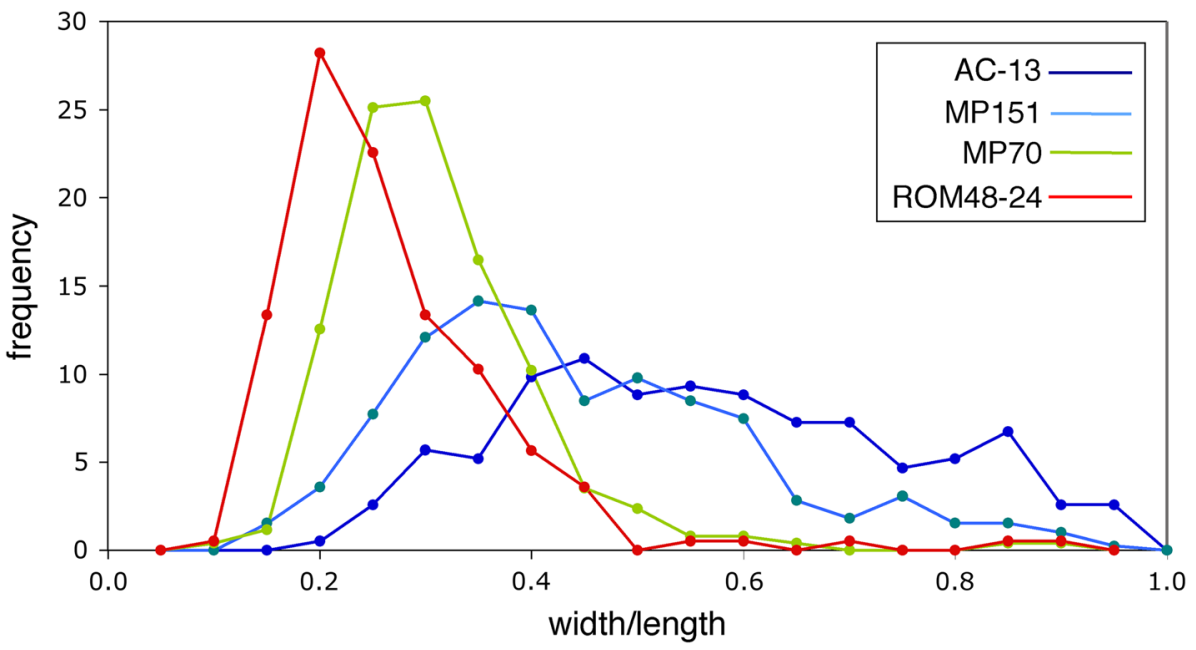

a symmetrical manner, with low marginal values rising to a maximum and then falling again smoothly towards the centre of the sill (to give an "M" shape; Fig. 5). There is no apparent effect of the weak flow alignment of plagioclase in the Traigh Bhàn na Sgùrra Sill. The distance from the margin of the maximum values is between 0.004 and 0.2 of the normalized distance across the sill and so ranges from a few tens of $\mathrm{cm}$ from the margins of the Traigh Bhàn na Sgùrra Sill to $\sim \mathrm{m}$ from the margins of the Whin Sill. The average aspect ratio across the two thickest sills in this study varies asymmetrically, with a pronounced marginal reduction within the basal 10$12 \mathrm{~m}$, but continued increase to higher values at the roof (Fig. 6). Note, however, that the sample spacing in the upper parts of both the Basement and Koffiefontein sills may not be sufficient to detect a deflection in the observed trend.

The average aspect ratio through the Makaopuhi lava lake is strongly asymmetric, with well-defined marginal reductions and a minimum value significantly offset to the lower part of the lake (Fig. 7). The overall M-shape variation in aspect ratio is complicated by the four lowermost samples in which the aspect ratio increases towards the lake floor. The stratigraphic height of the minimum values corresponds to that of the olivine-enriched horizon, which is likely to be the horizon that remained liquid for longest. Aspect ratios calculated using the average lengths of the long and short axes reported by Moore and Evans (1967) result in a similar pattern, though with more scatter and generally higher values of average aspect ratio.

There is no correlation between average aspect ratio and the average long axis length when the sills and lava lake are considered as a whole (Fig. 8). There is a weak negative correlation for some of the sills when considered individually, indicating that average long axis length does not closely track average aspect ratio across each sill.
When all the sills and the lava lake are considered together, the average long axis length and calculated crystallization times are positively correlated (Fig. 9), with the notable exception of the Basement Sill, in which long axes are much shorter than might be expected from the slow crystallization time (as previously pointed out by Holness et al. (2012)).

In contrast, there is a very strong negative correlation between the average aspect ratios and calculated crystallization times (Fig. 10) with the exception of those marginal samples with reduced aspect ratios- these have lower aspect ratios than would be expected for their short crystallization times. Neglecting these marginal samples provides a best-fit correlation of:

$$
\begin{aligned}
\log (\text { crystallization time })= & -1.79(\text { average aspect ratio }) \\
& +6.34 \quad R^{2}=0.94
\end{aligned}
$$

The aspect ratios in the four samples from the Skaergaard dykes are shown in Fig. 10 and also in Table 2 (together with grain size information from Holness et al. (2013)).

\section{Discussion}

The control of cooling rate on plagioclase grain shape

Higgins (1996) and Higgins and Chandrasekharam (2007) suggested, following the experimental results of Kouchi et al. (1986), that crystals become more acicular with increasing strength of stirring and advection of magma past the growing crystal. If this were the predominant control on plagioclase shape, convection would necessarily have been more vigorous in the thinner sills as these contain the higher aspect ratio grains. Analogously, the strength of stirring and convection would also necessarily have been 
Table 1 The number of grains measured in each sample is given by $n$, height gives the distance from the base of the sill (or lava lake) in metres, long gives the average of the long axes of each grain as measured in thin section, in millimetres. The aspect ratio is the aver- age of the apparent aspect ratios of $n$ grains as measured in thin section, with lower and upper giving the lower and upper $2 \sigma$ confidence intervals on the average value. The cooling time is given in years and was calculated according to details given in the text

\begin{tabular}{|c|c|c|c|c|c|c|c|}
\hline Sample & Height & $n$ & Long & Aspect ratio & Lower & Upper & Cooling time \\
\hline \multicolumn{8}{|c|}{ Traigh Bhan na Sgurra sill, traverse ROM48, thickness $3.5 \mathrm{~m}$} \\
\hline ROM48-6 & 0.06 & 190 & 0.13 & 4.54 & 4.37 & 4.77 & 0.00022 \\
\hline ROM48-24 & 0.24 & 195 & 0.16 & 4.80 & 4.59 & 5.00 & 0.0035 \\
\hline ROM48-32 & 0.32 & 232 & 0.18 & 4.54 & 4.30 & 4.80 & 0.0062 \\
\hline ROM48-75 & 0.75 & 181 & 0.21 & 4.33 & 4.04 & 4.56 & 0.030 \\
\hline ROM48-106 & 1.06 & 195 & 0.21 & 4.40 & 4.24 & 4.67 & 0.052 \\
\hline ROM48-169 & 1.69 & 263 & 0.25 & 4.09 & 3.80 & 4.31 & 0.077 \\
\hline ROM48-219 & 2.19 & 166 & 0.22 & 4.21 & 3.98 & 4.44 & 0.066 \\
\hline ROM48-318 & 3.18 & 185 & 0.21 & 4.63 & 4.34 & 4.86 & 0.0062 \\
\hline ROM48-350A & 3.45 & 255 & 0.18 & 4.31 & 4.11 & 4.53 & $1.56 \times 10^{-4}$ \\
\hline ROM48-350B & 3.50 & 193 & 0.17 & 4.25 & 4.00 & 4.44 & - \\
\hline \multicolumn{8}{|c|}{ Traigh Bhan na Sgurra sill, traverse ROM43, thickness $3.1 \mathrm{~m}$} \\
\hline ROM43-BASE & 0 & 129 & 0.03 & 3.94 & 3.77 & 4.08 & - \\
\hline ROM43-35 & 2.75 & 247 & 0.10 & 3.98 & 3.80 & 4.14 & 0.0073 \\
\hline ROM43-60 & 2.50 & 205 & 0.11 & 4.60 & 4.40 & 4.76 & 0.020 \\
\hline ROM43-80 & 2.30 & 249 & 0.11 & 4.34 & 4.24 & 4.63 & 0.032 \\
\hline ROM43-110 & 2.00 & 225 & 0.11 & 4.07 & 3.90 & 0.26 & 0.049 \\
\hline ROM43-170 & 1.40 & 405 & 0.18 & 4.07 & 3.87 & 4.27 & 0.059 \\
\hline ROM43-190 & 1.20 & 217 & 0.17 & 3.99 & 3.74 & 4.20 & 0.054 \\
\hline ROM43-233 & 0.77 & 215 & 0.14 & 4.08 & 3.85 & 4.24 & 0.030 \\
\hline ROM43-272 & 0.38 & 210 & 0.15 & 4.82 & 4.57 & 5.03 & 0.0086 \\
\hline ROM43-303 & 0.07 & 124 & 0.04 & 4.26 & 4.02 & 4.47 & 0.00031 \\
\hline ROM43-310 & 3.10 & 135 & 0.03 & 3.85 & 3.65 & 3.95 & - \\
\hline \multicolumn{8}{|c|}{ Whin Sill, thickness $38.56 \mathrm{~m}$} \\
\hline E37084 & 0.98 & 203 & 0.20 & 3.19 & 3.03 & 3.31 & 0.06 \\
\hline E37083 & 2.42 & 172 & - & 3.43 & 3.20 & 3.63 & 0.36 \\
\hline E37082 & 2.91 & 184 & 0.26 & 3.66 & 3.42 & 3.82 & 0.52 \\
\hline E37081 & 3.31 & 152 & - & 3.60 & 3.46 & 3.73 & 0.67 \\
\hline E37080 & 4.63 & 189 & 0.29 & 3.65 & 3.47 & 3.83 & 1.28 \\
\hline E37079 & 5.47 & 148 & 0.28 & 3.57 & 3.37 & 3.78 & 1.75 \\
\hline E37077 & 6.54 & 182 & 0.29 & 3.48 & 3.32 & 3.6 & 2.43 \\
\hline E37074 & 8.62 & 195 & - & 3.17 & 3.00 & 3.3 & 3.93 \\
\hline E37062 & 16.09 & 205 & 0.31 & 3.00 & 2.78 & 3.12 & 8.80 \\
\hline E37053 & 24.68 & 195 & 0.36 & 3.07 & 2.91 & 3.2 & 7.72 \\
\hline E37052 & 28.08 & 212 & 0.31 & 3.12 & 2.89 & 3.24 & 5.36 \\
\hline E37047 & 30.82 & 177 & 0.32 & 3.30 & 3.13 & 3.44 & 3.28 \\
\hline E37046 & 31.69 & 208 & - & 3.52 & 3.32 & 3.7 & 2.66 \\
\hline E37044 & 33.59 & 206 & 0.31 & 3.46 & 3.26 & 3.61 & 1.47 \\
\hline E37043 & 33.74 & 255 & - & 3.38 & 3.25 & 3.54 & 1.39 \\
\hline E37042 & 34.48 & 195 & 0.30 & 3.42 & 3.28 & 3.56 & 1.01 \\
\hline \multicolumn{8}{|c|}{ Portal Peak sill, thickness $129 \mathrm{~m}$} \\
\hline $87-87$ & 0 & 185 & 0.11 & 3.16 & 2.95 & 3.35 & 0.001 \\
\hline $87-88$ & 0.5 & 246 & 0.20 & 4.14 & 3.86 & 4.41 & 0.02 \\
\hline $87-89$ & 2 & 203 & 0.27 & 4.14 & 3.86 & 4.43 & 0.32 \\
\hline $87-90$ & 5 & 175 & 0.31 & 3.05 & 2.88 & 3.30 & 1.56 \\
\hline $87-92$ & 11 & 166 & 0.34 & 3.01 & 2.82 & 3.19 & 7.72 \\
\hline
\end{tabular}


Table 1 continued

\begin{tabular}{|c|c|c|c|c|c|c|c|}
\hline Sample & Height & $n$ & Long & Aspect ratio & Lower & Upper & Cooling time \\
\hline $87-95$ & 20 & 201 & 0.30 & 2.73 & 2.56 & 2.87 & 23.64 \\
\hline $87-98$ & 29 & 198 & 0.30 & 2.61 & 2.43 & 2.72 & 45.05 \\
\hline $87-101$ & 38 & 211 & 0.33 & 2.62 & 2.49 & 2.73 & 67.92 \\
\hline $87-105$ & 50 & 167 & 0.37 & 2.48 & 2.38 & 2.61 & 93.26 \\
\hline $87-110$ & 65 & 222 & 0.31 & 2.66 & 2.52 & 2.79 & 105.43 \\
\hline $87-113$ & 74 & 231 & 0.32 & 2.62 & 2.48 & 2.74 & 99.63 \\
\hline $87-117$ & 86 & 174 & 0.32 & 2.51 & 2.30 & 2.70 & 78.54 \\
\hline $87-119$ & 98 & 177 & 0.36 & 2.22 & 2.08 & 2.35 & 48.88 \\
\hline $87-121$ & 110 & 122 & 0.39 & 2.19 & 2.05 & 2.30 & 20.50 \\
\hline $87-122$ & 116 & 136 & 0.40 & 2.71 & 2.53 & 2.86 & 9.84 \\
\hline $87-123$ & 122 & 197 & 0.44 & 3.47 & 3.20 & 3.68 & 3.04 \\
\hline $87-124$ & 126.5 & 226 & 0.31 & 4.33 & 4.04 & 4.63 & 0.32 \\
\hline $87-125$ & 128 & 234 & 0.21 & 4.18 & 3.93 & 4.40 & 0.06 \\
\hline $87-126$ & 129 & 95 & 0.04 & 3.37 & 3.11 & 3.47 & 0.001 \\
\hline \multicolumn{8}{|c|}{ Koffiefontein sill, thickness $189 \mathrm{~m}$} \\
\hline $1,127.3$ & 1.7 & 188 & 0.25 & 3.21 & 2.95 & 3.46 & 0.18 \\
\hline 1,125 & 4 & 161 & 0.27 & 2.92 & 2.71 & 3.08 & 1.00 \\
\hline 1,078 & 5 & 288 & 0.22 & 3.24 & 3.06 & 3.44 & 1.56 \\
\hline 1,073 & 10 & 271 & 0.29 & 3.30 & 3.14 & 3.45 & 6.20 \\
\hline $1,070.3$ & 12.7 & 188 & 0.39 & 3.26 & 3.06 & 3.48 & 9.94 \\
\hline 1,065 & 18 & 252 & 0.26 & 3.06 & 2.86 & 3.18 & 19.67 \\
\hline 1,060 & 23 & 234 & 0.33 & 2.86 & 2.62 & 3.09 & 31.51 \\
\hline 1,042 & 41 & 153 & 0.33 & 2.61 & 2.45 & 2.76 & 89.84 \\
\hline 944.6 & 84.4 & 116 & 0.43 & 2.43 & 2.3 & 2.57 & 220.07 \\
\hline 912 & 117 & 115 & 0.46 & 2.37 & 2.24 & 2.48 & 196.17 \\
\hline 871 & 158 & 100 & 0.40 & 2.26 & 2.10 & 2.38 & 54.97 \\
\hline 860 & 170 & 115 & 0.46 & 2.71 & 2.50 & 2.86 & 21.84 \\
\hline 853.5 & 176 & 203 & 0.43 & 3.17 & 2.87 & 3.40 & 10.41 \\
\hline 842.6 & 187 & 145 & 0.37 & 3.37 & 3.10 & 3.65 & 0.25 \\
\hline \multicolumn{8}{|c|}{ Basement sill, thickness $362 \mathrm{~m}$} \\
\hline AC-58 & 0 & 210 & 0.05 & 2.32 & 2.26 & 2.37 & 0.001 \\
\hline AC-57 & 6.3 & 198 & 0.07 & 2.66 & 2.55 & 2.74 & 2.48 \\
\hline AC-56 & 12.4 & 166 & 0.10 & 2.86 & 2.73 & 2.97 & 9.58 \\
\hline AC-55 & 19.9 & 203 & 0.07 & 2.68 & 2.56 & 2.77 & 24.52 \\
\hline AC-51 & 26.0 & 316 & 0.11 & 2.66 & 2.54 & 2.77 & 41.57 \\
\hline AC-50 & 32.4 & 186 & 0.10 & 2.50 & 2.38 & 2.62 & 63.95 \\
\hline AC-49 & 38.5 & 185 & 0.11 & 2.42 & 2.27 & 2.49 & 89.32 \\
\hline AC-44 & 69.7 & 138 & 0.16 & 2.25 & 2.1 & 2.36 & 268.57 \\
\hline AC-38 & 107.0 & 165 & 0.16 & 2.14 & 2 & 2.47 & 532.55 \\
\hline AC-19 & 144.4 & 201 & 0.19 & 2.14 & 2.04 & 2.25 & 749.50 \\
\hline AC-13 & 181.7 & 193 & 0.22 & 2.06 & 1.94 & 2.17 & 830.48 \\
\hline AC-11 & 190.0 & 169 & 0.20 & 2.01 & 1.92 & 2.1 & 825.45 \\
\hline AC-9 & 241.8 & 191 & 0.21 & 2.13 & 2.06 & 2.22 & 619.96 \\
\hline AC- 8 & 283.3 & 117 & 0.28 & 2.30 & 2.16 & 2.41 & 330.80 \\
\hline AC-7 & 324.8 & 170 & 0.26 & 2.49 & 2.35 & 2.6 & 83.59 \\
\hline AC-1 & 361.3 & 257 & - & 3.28 & 3.12 & 3.44 & 0.03 \\
\hline A-38 & 362.0 & 194 & 0.10 & 3.24 & 3.08 & 3.39 & 0.02 \\
\hline
\end{tabular}


Table 1 continued

\begin{tabular}{|c|c|c|c|c|c|c|c|}
\hline Sample & Height & $n$ & Long & Aspect ratio & Lower & Upper & Cooling time \\
\hline \multicolumn{8}{|c|}{ Prehistoric Makaopuhi lava lake, depth $68.6 \mathrm{~m}$} \\
\hline MP-53 & 67.7 & 199 & 0.11 & 3.56 & 3.33 & 3.71 & - \\
\hline MP-57 & 66.5 & 121 & 0.18 & 3.52 & 3.38 & 3.67 & - \\
\hline MP-70 & 62.5 & 255 & 0.13 & 3.84 & 3.64 & 4.01 & - \\
\hline MP-72 & 61.9 & 380 & - & 3.70 & 3.53 & 3.88 & - \\
\hline MP-87 & 57.3 & 480 & - & 3.39 & 3.24 & 3.56 & 1.80 \\
\hline MP-91 & 56.1 & 348 & 0.26 & 3.23 & 3.05 & 3.36 & 3.39 \\
\hline MP-103 & 52.4 & 356 & 0.30 & 3.00 & 2.87 & 3.13 & 5.89 \\
\hline MP-121 & 47.0 & 228 & 0.29 & 3.00 & 2.85 & 3.11 & 12.49 \\
\hline MP-151 & 37.8 & 389 & 0.30 & 2.77 & 2.58 & 2.93 & 22.38 \\
\hline MP-166 & 33.2 & 403 & 0.29 & 2.68 & 2.55 & 2.84 & 26.20 \\
\hline MP-191 & 25.6 & 283 & 0.22 & 2.54 & 2.31 & 2.68 & 32.03 \\
\hline MP-205 & 21.4 & 136 & 0.24 & 2.43 & 2.32 & 2.54 & 32.52 \\
\hline MP-218 & 17.4 & 155 & 0.24 & 2.65 & 2.54 & 2.75 & 29.15 \\
\hline MP-229 & 14.0 & 304 & - & 2.80 & 2.69 & 2.90 & 23.08 \\
\hline MP-240 & 10.7 & 233 & 0.16 & 2.87 & 2.7 & 3 & 14.54 \\
\hline MP-247 & 8.6 & 131 & 0.21 & 3.20 & 3.07 & 3.32 & 9.51 \\
\hline MP-256 & 5.8 & 305 & - & 2.94 & 2.82 & 3.01 & 5.21 \\
\hline MP-265 & 3.1 & 158 & 0.16 & 2.56 & 2.42 & 2.71 & - \\
\hline MP-270 & 1.5 & 204 & - & 2.68 & 2.56 & 2.81 & - \\
\hline MP-273 & 0.6 & 212 & - & 2.67 & 2.56 & 2.8 & - \\
\hline MP-275 & 0.0 & 216 & 0.07 & 2.82 & 2.66 & 2.97 & - \\
\hline
\end{tabular}
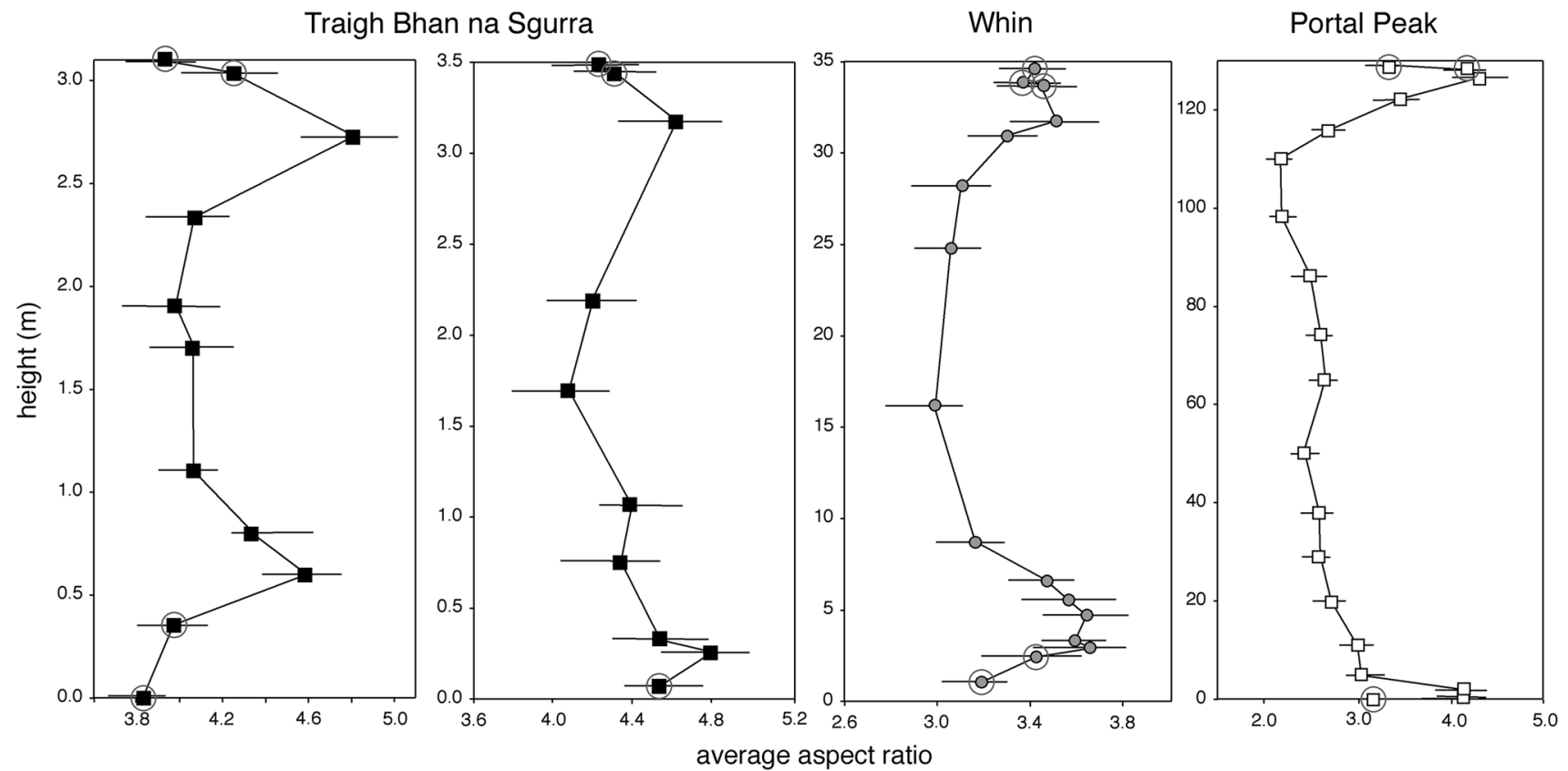

Fig. 5 Average apparent aspect ratio in three different sills, plotted as a function of height above the base. The Traigh Bhàn na Sgùrra Sill was sampled across two separate traverses. The pale grey circles surrounding the symbols at the base and top of each sill denote low aspect ratio marginal samples 


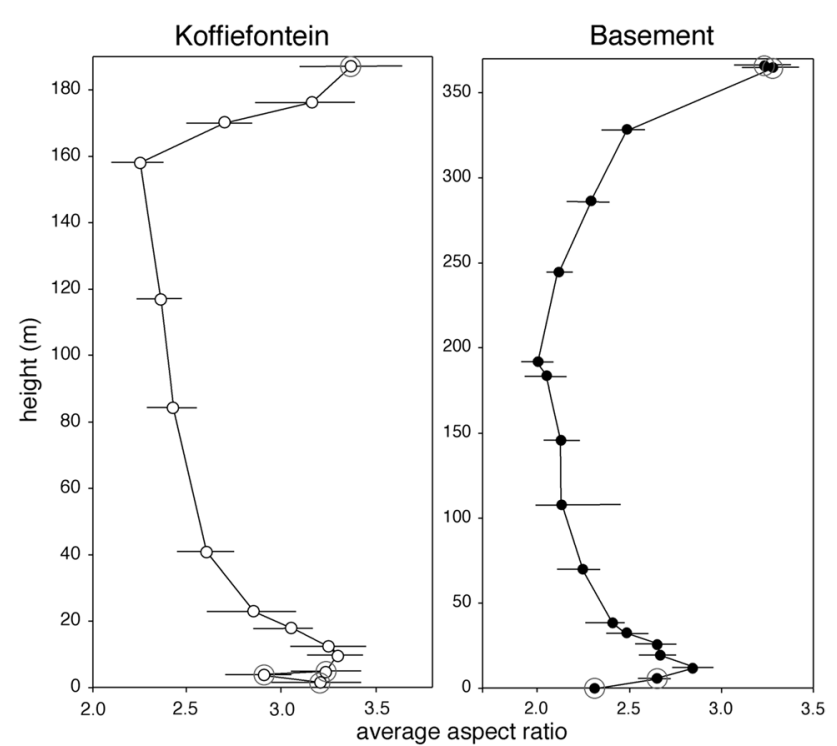

Fig. 6 Average apparent aspect ratio across two sills, plotted as a function of height above the base. The pale grey circles surrounding the symbols at the base of each sill denote low aspect ratio marginal samples. The topmost samples in each sill are also marked, as these have lower than expected aspect ratio for their crystallization times (see Fig. 10)

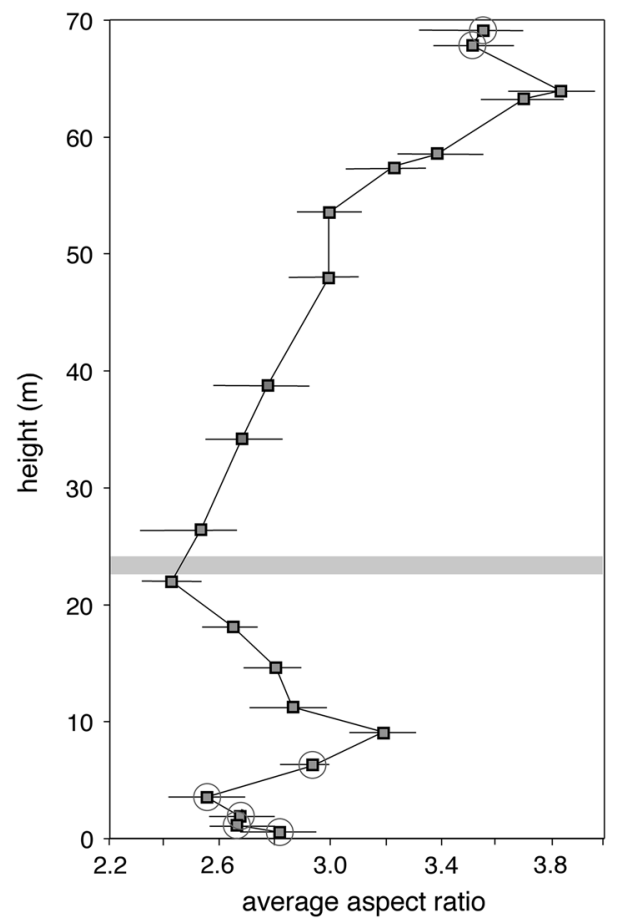

Fig. 7 Average apparent aspect ratio through the prehistoric Makaopuhi lava lake. The grey band shows the position of the layer rich in olivine phenocrysts, presumed to be the horizon with the slowest cooling rate (Moore and Evans 1967). The pale grey circles surrounding the symbols at the base and top of the lake denote low aspect ratio marginal samples greatest near sill margins. Neither of these situations is likely. Instead, the results presented here demonstrate that change in grain shape must be a consequence of a variation in the effect of cooling rate on the relative rates of growth of the different crystal faces.

Changes in cooling rate act unequally on the different growth faces of plagioclase (as shown in Fig. 1b). The (010) face is apparently not as sensitive to cooling rate as is the (100) face, with an intermediate response of the (001) face. One possible reason for this might be the presence of multiple lamellar twins parallel to (010), providing fast-growing interfaces where the twin planes emerge perpendicular to (010) (Dowty 1980; Franke and Ghobarkar 1980; Baronnet 1984). However, examination of twinned swallowtail grains shows that rapid growth occurs in the central part of the twins, rather than where the twin planes intersect the crystal faces, leaving a void at the twin boundary itself (Fig. 11), suggesting that such an effect may only play a role at relatively low growth rates. The difference in response of interface-controlled growth is therefore most likely to be a consequence of differences in the atomic structure or surface chemistry of plagioclase in the different growth directions (Baronnet 1984).

Plagioclase grain shape as a speedometer in dolerite intrusions

Notably, the correlation between grain shape and crystallization time enables us to constrain the duration of the crystallization interval to within an order of magnitude without depending on knowledge of growth rates, thus providing a robust measure of timescales. It is interesting that the abundance of orthopyroxene phenocrysts in parts of the Basement Sill does not affect the average aspect ratio, even though the grain size of the plagioclase in the orthopyroxene-rich horizons is relatively small compared to thinner (and presumably more rapidly cooled) bodies (Fig. 9). Aspect ratio is thus apparently independent of the actual range of grain sizes when compared between different intrusions.

The two thickest sills appear to have a rather different spatial variation of average aspect ratio to the thinner sills. The change from symmetrical to asymmetrical behaviour occurs between 130 and 189 m thickness and may relate to differences in fluid dynamical behaviour or filling history. As sills become thicker, they are more likely to be a result of multiple magma injections (e.g. Zieg and Marsh 2012), with a consequently longer cooling history (Cawthorn 2012). Thicker sills are also more likely to undergo vigorous and sustained convection, resulting in more effective heat loss through the roof (Huppert and Turner 1991). Both the Koffiefontein and the Basement sills are thought to 
Fig. 8 Average long axis length as a function of average apparent aspect ratio for all six bodies investigated

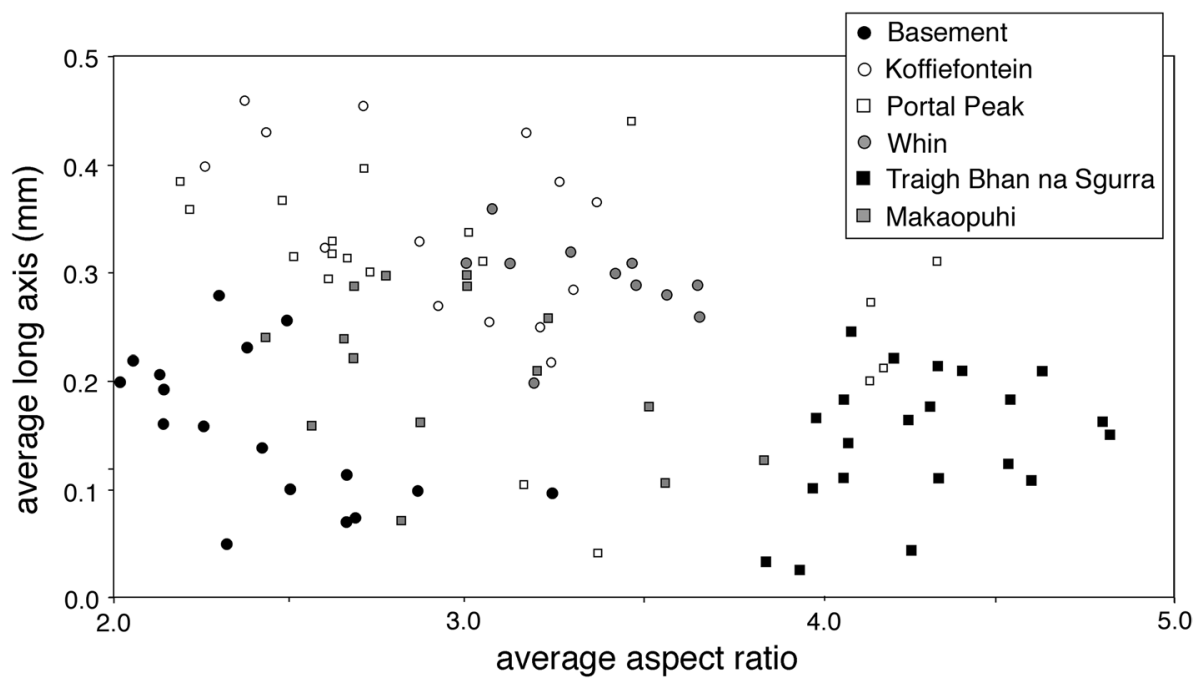

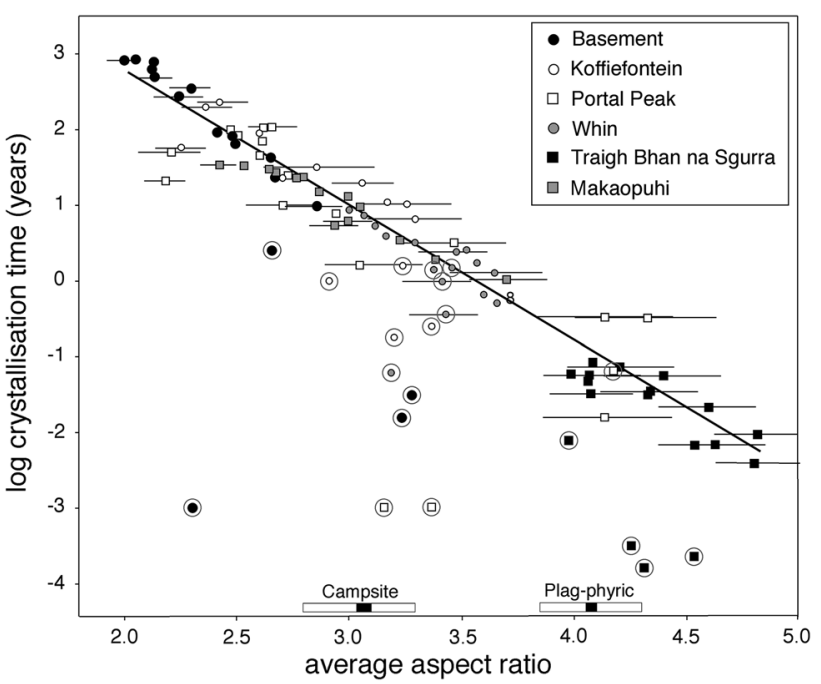

Fig. 10 Calculated crystallization time (in years) as a function of the average apparent aspect ratio. The data points enclosed by grey circles are the low aspect ratio samples from the marginal regions of the sills (see Figs. 5, 6). No marginal samples from the Makaopuhi lava lake are shown as their crystallization times could not be obtained from Moore and Evans (1967). The two boxes labelled Campsite and plagioclase-phyric show the average apparent aspect ratios and the $2 \sigma$ confidence intervals in the two dykes from the Skaergaard Campsite area

may relate to minor compositional differences between the different essentially basaltic bodies. The melt $\mathrm{H}_{2} \mathrm{O}$ content, for example, might affect grain shape via its effect on the extent of polymerization in the melt and consequently the rate of diffusion to the growth grain (Wagstaff and Richards 1966; Muncill and Lasaga 1988).

There is little in the literature with which to compare the new data and results. Plagioclase megacrysts in the Deccan Traps have (true 3-D) aspect ratios in the range 4-7 (Higgins and Chandrasekharam 2007), but it is not 
Table 2 The average aspect ratio of plagioclase from the Skaergaard Campsite area. The number of grains measured in each sample is given by $n$, and long gives the average length (in $\mathrm{mm}$ ) of the long axes as measured in thin section (from Holness et al. 2013). The upper and lower $2 \sigma$ confidence intervals on the average apparent aspect ratio are given

\begin{tabular}{llllll}
\hline Sample & $n$ & Long & Aspect ratio & Lower & Upper \\
\hline Campsite Dyke & & & & & \\
SK11-11-10 & 182 & 0.41 & 3.03 & 2.82 & 3.24 \\
SK11-11-12 & 223 & 0.30 & 3.10 & 2.89 & 3.29 \\
$\begin{array}{l}\text { Plagioclase-phyric Dyke } \\
\text { SK11-48A }\end{array}$ & 210 & 0.15 & 4.04 & 3.85 & 4.25 \\
SK11-50A & 501 & 0.24 & 4.10 & 3.86 & 4.32 \\
\hline
\end{tabular}
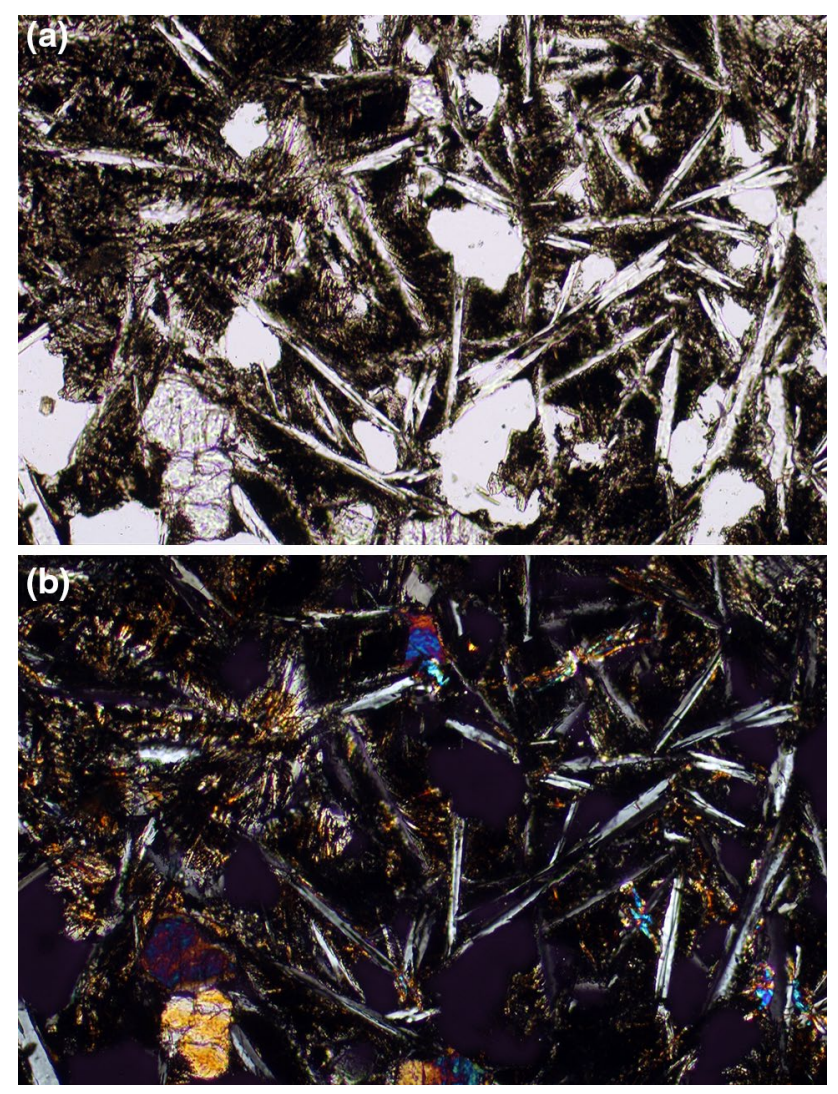

Fig. 11 Photomicrographs under a plane-polarized light and b crossed polars of a vesicular pillow basalt from Stapafell, Iceland (Harker Collection number 115623). The photographs are $4.5 \mathrm{~mm}$ across. Note the swallowtail plagioclase grains, each of which comprises 2-3 twins. The ends of the twin planes appear to prohibit growth, leaving an internal void in the rapidly growing crystals

clear that there is a direct comparison between the average aspect ratios observed in sills and lava lakes and those of phenocrysts in lava flows. Phenocrysts may have grown as isolated free-floating grains, whereas in the sills examined here, the final aspect ratios have been affected by impingement. Note, however, that if the phenocryst population is formed of fragments of a disaggregated low-porosity crystal mushy layer, the shape population would be directly comparable to that presented here. Comparison of the Deccan Traps phenocrysts with the data in Fig. 10 suggests a crystallization time between 1 and 200 years. Higgins and Chandrasekharam (2007) estimate growth times of $500-1,500$ years for the same population, but this estimate is based on the assumption of a (constant) growth rate of $10^{-10} \mathrm{~mm} \mathrm{~s}^{-1}$. They found no correlation between aspect ratio and the crystallization time calculated using the CSD method.

The Skaergaard Campsite dykes as a case study

The crystallization times for the sills and lava lake were calculated assuming an initial country rock temperature of $0{ }^{\circ} \mathrm{C}$, a plausible assumption given their geological setting and the strong correlation between calculated crystallization times and plagioclase grain shape (Fig. 10). This strong correlation can be used to detect shallow basaltic intrusions that have cooled more slowly than expected for their thickness and were therefore intruded into country rock that was significantly hotter than $0{ }^{\circ} \mathrm{C}$. A similar approach, based on the variation of clinopyroxene-plagioclase-plagioclase dihedral angles with cooling rate, was used by Holness et al. (2013) to place temporal constraints on the injection of the Skaergaard Campsite dykes into a recently solidified intrusion.

The best-fit line relating crystallization time to the average aspect ratios (Fig. 10) and the data presented in Table 2 suggest a crystallization time of 6-8 years for the central parts of the Campsite Dyke (with lower and upper limits of 3 and 19 years, respectively), and 0.1 years for the central parts of the plagioclase-phyric Dyke (with lower and upper limits of 0.05 and 0.27 years, respectively). Using the model of Holness et al. (2013), who calculated the time taken to crystallize as a function of the country rock temperature (assuming a crystallization interval of 1,200 $1,000{ }^{\circ} \mathrm{C}$ and the same latent heat and thermal diffusivity as used for the thermal model for the sills), these values of crystallization time are consistent with a country rock temperature of $800-930{ }^{\circ} \mathrm{C}$ at the time of intrusion of the Campsite Dyke, and with a country rock temperature at essentially that of the stable geotherm $\left(<50{ }^{\circ} \mathrm{C}\right)$ at the time of intrusion of the plagioclase-phyric Dyke (Fig. 12).

For the Campsite Dyke, the calculated country rock temperatures based on average plagioclase aspect ratio are similar to that based on the median clinopyroxene-plagioclase-plagioclase dihedral angle (Holness et al. 2013), confirming its status as one of the very earliest dykes that cut the Skaergaard intrusion, whereas the plagioclase-phyric Dyke was formed significantly later. The results presented 


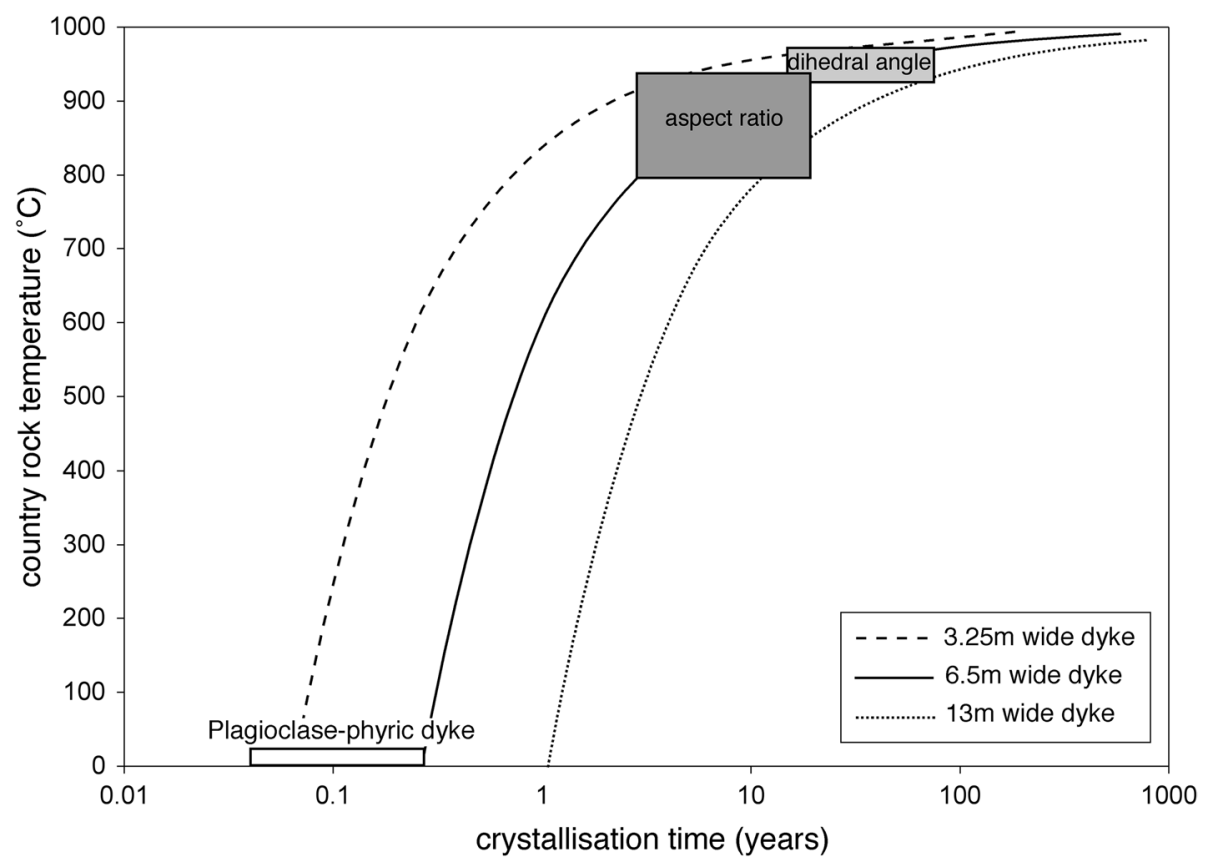

Fig. 12 Calculated crystallization times (in years) for the centre of dykes of various thickness as a function of the country rock farfield temperature. The median clinopyroxene-plagioclase-plagioclase dihedral angle in the Campsite Dyke has been used to suggest that the Skaergaard intrusion (at the current level of exposure) was at $920-970{ }^{\circ} \mathrm{C}$ at the time of dyke intrusion (Holness et al. 2013),

here show that the aspect ratio method is more informative than the dihedral angle method for the plagioclase-phyric Dyke because it can be used to detect crystallization times shorter than 1 year, in contrast to the dihedral angle method which is only useful if crystallization times are sufficiently long ( $>10$ years) to produce median dihedral angles significantly greater than $78^{\circ}$ (Holness et al. 2012).

The marginal reduction

A significant feature of all the bodies examined here is the reduction of average aspect ratio at the margins. The reduction in average aspect ratio occurs symmetrically in sills thinner than $130 \mathrm{~m}$, but (at least within the limitations of the sample spacing) appears to be well developed only at the base of the two thicker sills.

The marginal reduction cannot be related to the absolute cooling rate since it occurs at a distance from the margin that is approximately proportional to the total sill thickness. It therefore cannot correlate with any particular value of cooling rate since the distance from the margin at which the reduction begins correlates with a greater cooling rate in the thinner sills compared to the thicker. The maximum value of the average aspect ratio also varies between the sills, with higher values associated with thinner sills. These observations suggest that the marginal reduction is a whereas the aspect ratio method suggests a lower temperature range of $800-930{ }^{\circ} \mathrm{C}$. The high aspect ratios in the plagioclase-phyric Dyke are consistent with the Skaergaard intrusion having cooled to ambient temperatures at the time of dyke intrusion. The dihedral angle method was unable to resolve this, being consistent only with temperatures $<670{ }^{\circ} \mathrm{C}$ (Holness et al. 2013)

consequence of some kind of cross-over event, with two or more competing controls on plagioclase grain shape. Possible contributing factors are the initial grain shape and the timing of impingement in the developing crystal mush.

Critically, the average aspect ratio in the sills is that in fully solidified rocks. These crystals may have initially grown as essentially isolated grains, but with further growth, they impinged on other grains. Impingement of platy grains means that the grains can no longer continue to grow longer, but instead, must increase their thickness (Schiavi et al. 2009). While there has been extensive work done on the packings of rod-like particles (e.g. Philipse 1996), little is known about the packings of tabular particles, although comparison with rod-like particles suggests that impingement will occur at lower volume fractions in aggregates of less equant grains. Nucleation density may also play a role in determining the volume fraction at impingement. The higher the nucleation density, and the more elongated and platy the grains, the earlier in the crystallization history will impingement play a role. This means that although grains might initially grow with very elongate or platy shapes, early impingement will result in a much lower average aspect ratio since the later growth of plagioclase must result in thickening of existing grains rather than development of even greater (apparent) length. A further factor may be the duration of the nucleation event; if, for 
any given rock composition, all crystals nucleated simultaneously, the effects of impingement on the final population of grain shapes (and hence the average shape) would differ from those in an otherwise identical rock in which the crystals nucleated over a period of time. Because earlier nucleating, and hence earlier impinging, platy crystals will be thicker than later nucleating, and hence later impinging, crystals, a rock formed by a single burst of nucleation will have a lower average aspect ratio than a rock with the same plagioclase mode and nucleation density but an extended period of nucleation.

The correlation of average aspect ratio with cooling rate in the bulk of the sills demonstrates that short crystallization times lead to platy crystals with high aspect ratio. The corollary of this is that the initial, pre-impingement aspect ratio of the plagioclase grains in the sill margins was high, leading to early impingement compared to the sill centre. The volume fraction on impingement was therefore low in the sill margins, leading to a significant reduction in the final aspect ratio of the fully solidified dolerite. If preimpingement grain shape were the only factor controlling the final average aspect ratio, then one might expect average aspect ratio to decrease towards the sill centre.

Nucleation rates are a function of the degree of undercooling and are therefore likely to be controlled by absolute cooling rate. The number of nuclei (or nucleation density) at the margins of sills will be much higher than in the central parts. If nucleation density were the only factor affecting final aspect ratio, then one would expect the volume fraction at impingement to be lower at the margins than in the centre, leading to an increasing average aspect ratio towards the centre of each sill. The effect of high nucleation density on final grain shape will be increased by the likelihood that the aspect ratio in the earliest stages of growth may be significantly higher than that in later stages of solidification (Pupier et al. 2008).

The " $\mathrm{M}$ "-shaped profile of average aspect ratio across the thinner sills may thus be a consequence of the balance between the effects of initial aspect ratio, nucleation density and duration of nucleation, with nucleation kinetics playing a greater role at the sill margins and initial aspect ratio becoming more important in the sill centres. The inwards increasing average aspect ratio at the sill margins may thus reflect a reduction in the nucleation density, and a more extended period of nucleation, in the progressively slower cooled sill interior superimposed on the general cooling rate-controlled trend of decreasing aspect ratio. However, the nucleation density in the sills shows no consistent pattern that can be related to the M-shaped profiles: the Basement Sill is generally more fine-grained (using long axis lengths as a measure of grain size), with a therefore higher nucleation density compared to sills of very similar composition but much shorter solidification times (Fig. 9). The absence of a consistent pattern between the sills may be a consequence of differences in the number of available nuclei in the incoming magma. The marginal reduction in aspect ratio is therefore most likely a consequence of a complex series of interlinked processes and is by no means well understood.

A further consideration is that most of the marginal samples described here are unlikely to represent the original chilled material formed as the sill filled with magma. This is because magma flow during sill inflation is likely to result in melt-back of the early formed chill zones (Bruce and Huppert 1989). The chill zones preserved in many of the sills are therefore likely to have formed later, when the flow of magma had waned sufficiently to permit significant heat loss through the sill walls. The only sample traverse for which this is unlikely to have happened, for which the chill zone is therefore most likely to be that formed on the first arrival of magma, is the ROM43 traverse through the Traigh Bhàn na Sgùrra sill. This sample traverse is likely, therefore, to record the primary microstructures formed on magma injection, with a well-developed and symmetrical marginal reduction in aspect ratio.

\section{Conclusions}

The samples studied here were collected from a range of bodies of essentially basaltic bulk composition. While it would perhaps strengthen the results by comparing plagioclase grain shapes from a single body of widely varying thickness, thus removing any compositional variation, the data collected here appear to support the idea that plagioclase grain shape is relatively insensitive to small variations of magma composition but is highly sensitive to cooling rates.

The method of using plagioclase aspect ratio, as measured in thin section, constrains the crystallization time to within an order of magnitude. This can be done without knowing either the crystal growth rate or the 3-D crystal shape, both of which are needed for good constraints to be placed on growth times using the CSD method. A further advantage of the aspect ratio method is that it can be used to constrain crystallization times shorter than 1 year. A disadvantage of using aspect ratios is that spatial information is needed to determine whether or not the sample comes from the marginal regions of the body.

The application of the aspect ratio method to constrain timescales of crystallization in much larger gabbro bodies such as layered intrusions may not be straightforward. plagioclase grains in large intrusions are likely to be sourced from a wide range of locations in the chamber, each with its own distinctive growth conditions (e.g. Tepley and Davidson 2003). Other processes such as compaction-driven 
recrystallization may affect plagioclase grain shape (Meurer and Boudreau 1998). Floor and roof cumulates may also have strong grain fabrics, and this must be taken into account when measuring aspect ratios. It might be fruitful to examine those parts of layered intrusions in which compaction and crystal transport and rearrangement are unlikely to have been important, such as their walls in which plagioclase is likely to have grown in situ and to be randomly oriented.

Acknowledgments I am grateful to Rob Farr, Kathy Cashman and Grant Cawthorn for insightful discussions and to David Neave for the image shown in Fig. 1b. Careful and thoughtful comments from Julia Hammer and an anonymous reviewer helped clarify and improve an earlier version of the manuscript. Samples from Makaopuhi were kindly loaned by Roz Helz, with further samples donated by Bernard Evans. Samples from Portal Peak were loaned by Australian National University and I am grateful to Gordon Lister for making this possible. Samples from the Whin Sill were loaned by the British Geological Survey. The Basement Sill samples were kindly provided by Amanda Charrier, and those of the Koffiefontein Sill (together with the geological details of the sill) by Grant Cawthorn. The work was supported by the Natural Environment Research Council [Grant Number NE/J021520/1] and the Royal Society via an International Joint Project Grant.

Open Access This article is distributed under the terms of the Creative Commons Attribution License which permits any use, distribution, and reproduction in any medium, provided the original author(s) and the source are credited.

\section{References}

Baronnet A (1984) Growth kinetics of the silicates: a review of basic concepts. Fortschr Mineral 62:187-232

Becke F (1911) Uber die Ausbildung der Zwillingskristalle. Fortschr Mineral Kristallogr Petrogr 1:68-85

Bedard JH, Marsh BD, Hersum TG, Naslund HR, Mukasa SB (2007) Large-scale mechanical redistribution of orthopyroxene and plagioclase in the Basement sill Ferrar Dolerites McMurdo Dry Valleys Antarctica: petrological mineral-chemical and field evidence for channelized movement of crystals and melt. J Petrol 48:2289-2326

Brooks CK, Nielsen TFD (1978) Early stages in the differentiation of the Skaergaard magma as revealed by a closely related suite of dike rocks. Lithos 11:1-14

Bruce PM, Huppert HE (1989) Thermal control of basaltic fissure eruptions. Nature 342:665-667

Brugger CR, Hammer JE (2010) Crystal size distribution analysis of plagioclase in experimentally decompressed hydrous rhyodacite magma. Earth Planet Sci Lett 300:246-254

Burkhard DJM (2002) Kinetics of crystallization: example of microcrystallisation in basalt lava. Contrib Mineral Petrol 142:724-737

Burkhard DJM (2005) Nucleation and growth rates of pyroxene plagioclase and $\mathrm{Fe}-\mathrm{Ti}$ oxides in basalt under atmospheric conditions. Eur J Mineral 17:675-685

Cabane H, Laporte D, Provost A (2005) An experimental study of Ostwald ripening of olivine and plagioclase in silicate melts: implications for the growth and size of crystals in magmas. Contrib Mineral Petrol 150:37-53

Cashman KV (1993) Relationship between plagioclase crystallization and cooling rates in basaltic melts. Contrib Mineral Petrol 113:126-142
Cawthorn RG (2012) Multiple sills or a layered intrusion? Time to decide. S Afr J Geol 115:283-290

Dowty E (1980) Crystal growth and nucleation theory and the numerical simulation of igneous crystallization. In: Hargraves RB (ed) Physics of magmatic processes. Princeton University Press, Princeton, pp 419-486

Dunham AC, Strasser-King VEH (1981) Petrology of the Great Whin Sill in the Throckley borehole Northumberland. Report of the Institute of Geological Sciences 81/4

Evans BW, Moore JG (1968) Mineralogy as a function of depth in the prehistoric Makaopuhi tholeiitic lava lake, Hawaii. Contrib Mineral Petrol 17:85-115

Faure G, Mensing T (2010) The Transantarctic Mountains: rocks ice meteorites and water. Springer, New York

Faure F, Trolliard G, Nicollet C, Montel J-M (2003) A developmental model of olivine morphology as a function of the cooling rate and the degree of undercooling. Contrib Mineral Petrol 145:251-263

Fenn PM (1977) The nucleation and growth of alkali feldspars from hydrous melts. Can Mineral 15:135-161

Franke W, Ghobarkar H (1980) Die Morphologie von Albit beim Wachstum aus überkritischer Phase. Z Phys Chem Neue Folge 122:43-51

Franke W, Ghobarkar H (1982) The morphology of hydrothermally grown plagioclase. Cryst Res Technol 17:459-464

Ghiorso MS (1997) Thermodynamic models of igneous processes. Annu Rev Earth Planet Sci 25:221-241

Hergt JM, Chappell BW, Faure G, Mensing TM (1989) The geochemistry of Jurassic dolerites from Portal Peak Antarctica. Contrib Mineral Petrol 102:298-305

Higgins MD (1994) Numerical modeling of crystal shapes in thin sections: estimation of crystal habit and true size. Am Mineral 79:113-119

Higgins MD (1996) Magma dynamics beneath Kameni volcano, Thera, Greece, as a revealed by crystal size and shape measurements. J Volcanol Geotherm Res 70:37-48

Higgins MD (2000) Measurement of crystal size distributions. Am Mineral 85:1105-1116

Higgins MD, Chandrasekharam D (2007) Nature of sub-volcanic magma chambers Deccan Province India: evidence from quantitative textural analysis of plagioclase megacrysts in the Giant Plagioclase Basalts. J Petrol 48:885-900

Holness MB, Humphrey MCS (2003) The Traigh Bhan na Sgurra sill Isle of Mull: flow localization in a major magma conduit. J Petrol 44:1961-1976

Holness MB, Richardson C, Helz RT (2012) Disequilibrium dihedral angles in dolerite sills: a new proxy for cooling rate. Geology 40:795-798

Holness MB, Richardson C, Andersen JCO (2013) The campsite dykes: a window into the early post-solidification history of the Skaergaard Intrusion East Greenland. Lithos 182-183:134-149

Huppert HE, Turner JS (1991) Comments on "On convective style and vigor in sheet-like magma chambers" by Bruce Marsh. J Petrol 32:851-854

Ikeda Y (1977) Grain size of plagioclase of the basaltic andesite dikes Iritono central Abukuma plateau. Can J Earth Sci 14:1860-1866

Irvine TN, Andersen JCO, Brooks CK (1998) Included blocks (and blocks within blocks) in the Skaergaard intrusion: geologic relations and the origins of rhythmic modally graded layers. Geol Soc Am Bull 110:1398-1447

Jackson KA (1958) Interface structure. In: Doremus RH, Roberts BW, Turnbull D (eds) Growth and perfection of crystals. Wiley, New York

Jackson K, Uhlmann D, Hunt J (1967) On the nature of crystal growth from the melt. J Cryst Growth 1:1-36

Jakobsen JK, Tegner C, Brooks CK, Kent AJR, Lesher CE, Nielsen TFD, Widenbeck W (2010) Parental magma of the Skaergaard 
intrusion: constraints from melt inclusions in primitive troctolite blocks and FG-1 dykes. Contrib Mineral Petrol 159:61-79

Kirkpatrick RJ (1975) Crystal growth from the melt: a review. Am Mineral 60:798-814

Kirkpatrick RJ (1981) Kinetics of crystallization of igneous rocks. Mineral Soc Am Rev Mineral 8:321-398

Kirkpatrick RJ, Robinson GR, Hays JF (1976) Kinetics of crystal growth from silicate melts: anorthite and diopside. J Geophys Res 81:5715-5720

Kitamura M, Hosoya S, Sunagawa I (1979) Re-investigation of the re-entrant corner effect in twinned crystals. J Cryst Growth 47:93-99

Kouchi A, Tsuchiyama A, Sunagawa I (1986) Effect of stirring on crystallisation kinetics of basalt: texture and element partitioning. Contrib Mineral Petrol 93:429-438

Koyaguchi T, Hallworth MA, Huppert HE, Sparks RSJ (1990) Sedimentation of particles from a convecting fluid. Nature 343:447-450

Latypov R, Egorova V (2013) Origin of mafic-ultramafic sills: new insights from $\mathrm{M}$ - and S-shaped mineral and whole-rock compositional profiles. EGU General Assembly 2013 abstract EGU2013-2937

Lofgren G (1974) An experimental study of plagioclase crystal morphology: isothermal crystallization. Am J Sci 274:243-273

Marsh BD (1988) Crystal size distribution (CSD) theory in rocks and the kinetics and dynamics of crystallization I. Theory. Contrib Mineral Petrol 99:277-291

Meurer WP, Boudreau AE (1998) Compaction of igneous cumulates Part II: compaction and the deveopment of igneous foliations. J Geol 106:293-304

Moore JG, Evans BE (1967) The role of olivine in the crystallisation of the prehistoric Makaopuhi tholeiitic lava lake Hawaii. Contrib Mineral Petrol 15:202-223

Morgan DJ, Jerram DA (2006) On estimating crystal shape for crystal size distribution analysis. J Volcanol Geotherm Res 154:1-7

Muncill GE, Lasaga AC (1988) Crystal-growth kinetics of plagioclase in igneous systems: isothermal $\mathrm{H}_{2} \mathrm{O}$-saturated experiments and extension of a growth model to complex silicate melts. Am Mineral 73:982-992

Neave DA, Passmore E, Maclennan J, Fitton JG, Thordarson T (2013) Crystal-melt relationships and the record of deep mixing and crystallization in the AD 1783 Laki eruption Iceland. J Petrol 54:1661-1690

Nielsen TFD (1978) The Tertiary dike swarms of the Kangerdlugssuaq area East Greenland. An example of magmatic development during continental break-up. Contrib Mineral Petrol 67:63-78

Nielsen TFD (2004) The shape and volume of the Skaergaard Intrusion. Greenland: implications for mass balance and bulk composition. J Petrol 45:507-530
Oze C, Winter JD (2005) The occurrence vesiculation and solidification of dense blue glassy pahoehoe. J Volcanol Geotherm Res 142:285-301

Passmore E, Maclennan J, Fitton JG, Thordarson T (2012) Mush disaggregation in basaltic magma chambers: evidence from the $\mathrm{AD}$ 1783 Laki eruption. J Petrol 35:2593-2623

Philipse AP (1996) The random contact equation and its implications for (colloidal) rods in packings suspensions and anisotropic powders. Langmuir 12:1127-1133

Preston RJ (1996) The petrogenesis of the Loch Scridain xenolithic sill complex, Isle of Mull. Unpublished $\mathrm{PhD}$ thesis, University of Glasgow. http://theses.gla.ac.uk/2089/

Preston RJ, Bell BR, Rogers G (1998) The Loch Scridain xenolithic sill complex, Isle of Mull, Scotland: fractional crystallization, assimilation, magma-mixing and crustal anatexis in subvolcanic conduits. J Petrol 39:519-550

Pupier E, Duchene S, Toplis MJ (2008) Experimental quantification of plagioclase crystal size distribution during cooling of a basaltic liquid. Contrib Mineral Petrol 155:555-570

Schiavi F, Walte N, Keppler H (2009) First in situ observation of crystallization processes in a basaltic andesitic melt with the moissanite cell. Geology 37:963-966

Slement C (2010) The extent of fractionation and mineral accumulation in a 190 m thick Karoo sill near the Gariep Dam. Unpublished Honours project University of the Witwatersrand South Africa

Stranski IN (1928) Zur Theorie des Kristallwachstums. Z Phys Chem A36:259-278

Swanson SE (1977) Relation of nucleation and crystal growth rate to the development of granitic textures. Am Mineral 62:966-978

Tepley FJ, Davidson JP (2003) Mineral-scale Sr-isotope constraints on magma evolution and chamber dynamics in the Rum layered intrusion Scotland. Contrib Mineral Petrol 145:628-641

Wager LR, Deer WA (1939) Geological investigations in East Greenland. Pt III. The petrology of the Skaergaard intrusion.Kangerdlugssuaq East Greenland. Medd om Grønl 105:1-352

Wagstaff FE, Richards KJ (1966) Kinetics of crystallization of stoichiometric $\mathrm{SiO}_{2}$ glasses in $\mathrm{H}_{2} \mathrm{O}$ atmospheres. J Am Ceram Soc 49:118-121

Williams SR, Philipse AP (2003) Random packings of spheres and spherocylinders simulated by mechanical contraction. Phys Rev E 67:051301. doi:10.1103/PhysRevE.67.051301

Zieg MJ, Marsh BD (2012) Multiple reinjections and crystal-mush compaction in the Beacon Sill McMurdo Dry Valleys Antarctica. J Petrol 53:2567-2591 